\title{
WestVirginiaUniversity
}

THE RESEARCH REPOSITORY @ WVU

Graduate Theses, Dissertations, and Problem Reports

2021

\section{The Media's Framing of Incarceration in West Virginia}

\author{
Patrick John Orsagos \\ West Virginia University, pjo0002@mix.wvu.edu
}

Follow this and additional works at: https://researchrepository.wvu.edu/etd

Part of the Communication Technology and New Media Commons, Journalism Studies Commons, Mass Communication Commons, and the Social Justice Commons

\section{Recommended Citation}

Orsagos, Patrick John, "The Media's Framing of Incarceration in West Virginia" (2021). Graduate Theses, Dissertations, and Problem Reports. 10192.

https://researchrepository.wvu.edu/etd/10192

This Problem/Project Report is protected by copyright and/or related rights. It has been brought to you by the The Research Repository @WVU with permission from the rights-holder(s). You are free to use this Problem/Project Report in any way that is permitted by the copyright and related rights legislation that applies to your use. For other uses you must obtain permission from the rights-holder(s) directly, unless additional rights are indicated by a Creative Commons license in the record and/ or on the work itself. This Problem/Project Report has been accepted for inclusion in WVU Graduate Theses, Dissertations, and Problem Reports collection by an authorized administrator of The Research Repository @ WVU. For more information, please contact researchrepository@mail.wvu.edu. 
The Media's Framing of Incarceration in West Virginia

Patrick Orsagos

Professional Report submitted to the Reed College of Media

at West Virginia University

in partial fulfillment of the requirements for the degree of

Master of Science in

Journalism

Mary Kay McFarland, M.S., Chair

Bob Britten, Ph.D.

Jesse Wright, M.S.

Glynis Board

Department of Journalism

Morgantown, West Virginia

2021

Keywords: mass incarceration, bail reform, West Virginia legislature, podcast, solutions journalism, thematic frame, episodic frame

Copyright 2021 Patrick Orsagos 
Abstract

The Media's Framing of Incarceration in West Virginia

\section{Patrick Orsagos}

The following is a professional project that examines the way in which the mass incarceration of West Virginians has been framed by the news media. The research presented explains the scope of the problem of mass incarceration, followed by an explanation of research conducted on framing. The literature review explores what other media scholars have published about framing and argues which frame is most dominant in crime reporting by state media. Following this is a methodology for production of a podcast series that utilizes a thematic frame and the practice of solutions journalism to promote dialogue around the systemic issues that lead to and result from the mass incarceration of people in the state. The podcast reports on a bill passed in the West Virginia state legislature that encourages judges to release people accused of certain, nonviolent crimes out on personal recognizance bonds. It strives to bring awareness to the flaws in the systems in West Virginia prisons and examine certain policies that define criminal action. The last part of the paper proposes an assessment of the completed podcast and parameters for a discussion. 


\section{Acknowledgements}

This project would not have been possible without the guidance and mentorship of Professor Mary Kay McFarland. I never would have explored the topic of incarceration in West Virginia without taking her class. Her class and her teaching opened my eyes to the possibilities of storytelling and the avenues that good journalism can create. Her mentorship and guidance have made all the difference in my academic and college experience.

Special thanks to the other members on my committee, Dr. Bob Britten, Glynis Board 2and Professor Jesse Wright. I've been fortunate enough to spend a lot of time with Dr. Britten in my undergraduate years and it has been wonderful. His teaching is one of the main reasons I stayed interested and engaged in journalism, and I have learned so much from him. He has pushed me to think so far out-of-the-box that at times, I thought my brain would explode, but it has proven to make me a more critical and open thinker. Thank you, Glynis for your edits and expertise in the audio realm. I really enjoyed our final editing sessions over the summer. Professor Wright, thank you for your expertise, you made this project better.

Lastly, I'd like to thank Ty, Therese, Claire (for making a last minute graphic of the podcast for publication), Elizabeth, Sydney and Anna for being my support system, listening to numerous rants and existential crises over these last few years. I'd also like to thank my parents whose standards have kept me motivated to perform and whose love and care have given me more than I could ever repay. I couldn't have done it without your support. 
Table of Contents

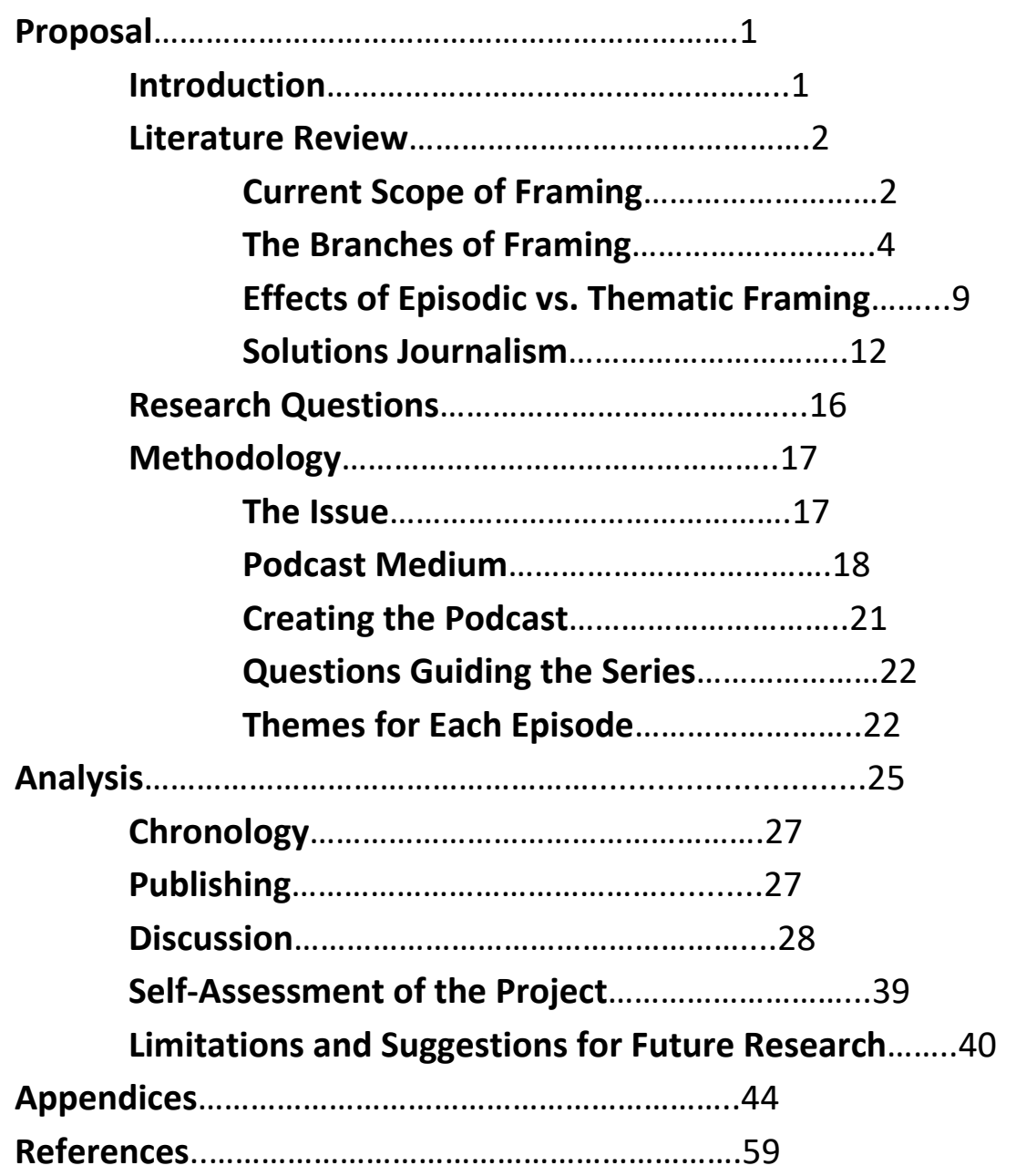




\section{Introduction}

Since the 1980s, there has been a rise in the number of people being incarcerated annually across the United States (Prison Policy Initiative 2019). West Virginia is no exception. Arguments have been made that the War on Drugs, instituted by President Richard Nixon, and President Ronald Regan's initialization of mandatory minimum sentences for drug crimes, are two main factors for the skyrocketing number of incarcerated people. These two pieces of legislation along with the opioid epidemic have hit West Virginia extremely hard (Vera Institute 2017). From 2004 to 2018, drug crimes in the mountain state rose 220 percent, according to the West Virginia Division of Corrections and Rehabilitation (White 2019). The DCR also reported that a little more than 25 percent of those admitted to state prisons or jails in 2018 required detox due to substance use disorder. Only 1.43 percent required detox in 2013 (White 2019). A significant amount of research has been conducted to examine why the United States incarcerates the most people in the world (Prison Policy Initiative 2019), but there has not been sufficient research conducted to study the media's influence on the public's perception of the criminal justice system. Nor has there been research to analyze the ways in which the media has framed stories related to incarceration, and the effects of that framing.

Within the last 40 years, women in the United States have been incarcerated at rates that are increasing faster than their male counterparts (Prison Policy Initiative 2019). The number of women admitted to prison in West Virginia has increased $677.5 \%$ since 1989 (Corrections Statistical Analysis Tool 2019). West Virginia is one of the states where the number of women being incarcerated is outpacing the space the state has for them. As of early October 2019 (Orsagos 2020), more than a quarter of the women sentenced to prison in West Virginia 
were serving those sentences in regional jails, where they did not have access to the same educational, career enhancement and rehabilitative services as the women in Lakin Correctional Center, the state's only female prison. In addition to the lack of space needed to house women, they have physical and emotional needs that differ from men, and structurally and systemically, prisons were built for men. Women in jail are also more likely to suffer from mental health problems and severe psychological distress than either women in prisons or men in both incarceral settings (Sawyer 2017).

These issues have gone under-reported by state media outlets, and much of the news covered in this area fails to report on viable solutions to both help the individuals incarcerated and reduce the amount of taxpayer money needed to pay for the growing number of people being incarcerated. This study examines the power the press has in its reporting on incarceration. It will study the concept of how the news media frames crime and the potential effects of that framing. Framing is an integral component in media studies because of the power that exists in it. Media have the ability to engage audiences and encourage them to think or respond in certain ways. The literature review in the next section examines the research that has already been conducted on how this issue has been framed in the media as well as research into alternative ways to frame the issue.

\section{Literature Review}

\section{Current Scope of the Study of Framing}

Framing is defined in a variety of ways by different researchers. Gamson and Modigliani (1987) say that a frame is "a central organizing idea or story line that provides meaning to an unfolding strip of events weaving a connection among them. The frame suggests what the 
controversy is about, the essence of the issue," (p. 143). In this view of a frame, its purpose is to string together stories through a central theme, but there is more to unpack. Pan and Kosicki (2001) say that "framing an issue is more a strategic means to attract more supporters, to mobilize collections, to expand actors' realm of influences, and to increase their chances of winning" (p. 92). In this reference, framing is seen as a means for the end goal of persuasion. The existing frame can be discovered through the knowledge of the reporter's motives or their expectations of their impact on the audience. A frame itself, is extracting a theoretical idea from a text and explaining its impact on the text and on the audience. Entman (1993) says, "[t]o frame is to select some aspects of a perceived reality and make them more salient in a communicating text, in such a way as to promote a particular problem, definition, causal interpretation, moral evaluation, and/or treatment recommendation" (p. 52). In each of these interpretations of a frame, a deep analysis of the text, and the context surrounding the topic of the story is the only way to firmly grasp the implications of a frame. What is most interesting about frames is that they are sometimes incredibly difficult to decipher while casually reading a story. Once they're discovered, they're almost impossible not to consider while reading in the future.

If a frame can influence the way in which an audience responds to a story, then journalists need to be cognisant of their intentional or unintentional framing. A frame can impact an entire story or a collection of stories. Pan and Kosicki (2001) say "frames define the boundaries of the discourse concerning an issue and categorize the relevant actors based on some established scheme of social taxonomy," to describe the influence of a frame.

Regardless of the job or intention of the creator, frames help to structure the audience's 
response to the story. If as Pan and Kosicki write, the frame defines the boundaries of the discourse, it follows that it limits discourse to those boundaries.

\section{The Branches of Framing}

There are two main types of frames: episodic and thematic. Each of these shape stories in different ways that encourage the audience to react in different ways. Kimberly Gross (2006) says that "episodic frames present an issue by offering a specific example, case study or eventoriented report" (p.6). The episodic frame is like a telephoto lens to the coverage of an issue or event (Benjamin 2007). In contrast, thematic frames place issues into a broader context where commentary by experts is often included. Thematic frames utilize a wider angle that focuses on the institutions or systems that are responsible for an event happening. Depending on the type of frame used to cover the mass incarceration of West Virginians, the stories will send different messages.

According to lyengar (1990), episodic frames describe concrete events and particular cases that illuminate an issue (p. 22). This kind of frame is likely to focus on an individual or a specific event, treating its audience as customers of the news (Benjamin 2007). The purpose of the episodic frame is to shed light on an individual or event, not to draw an emotional reaction toward government or institutions. Iyengar (1991) found that individuals shown episodic TV reports were less likely to consider society responsible than individuals exposed to thematic TV reports.

Television station WBOY covers north-central West Virginia. It's coverage of New England crime boss Whitey Bulger's death is an example of a story using episodic framing. 
There are three updates to the story, the first explains the initial findings, that Whitey Bulger, 89 years old, was moved to USP Hazelton while he served two life sentences for racketeering charges. Then, the story states that a man was found dead at the prison, and the president of the Local 420 of the American Federation of Government Employees is quoted saying that the death appeared to be a murder. Less than an hour later, WBOY updated the story and confirmed that Bulger was the victim of the murder. He was the third inmate killed at Hazelton in the previous seven months. Finally, the story was updated shortly after that to explain when and where Bulger was found unconscious and confirming that the FBI was beginning an investigation (Staff 2018). The episodic frame is used for this breaking news story because the story was a continuous update of an event, which was the death of Bulger. The reporters at WBOY updated the story as they found out what happened. The reporter presented the information, in this case an event, and that is all. There is no analysis that includes discussion of how many guards were employed, a look back at the other deaths and how those occurred, procedures in place to keep these instances from occurring and how or why those procedures failed. Even though this story was breaking news, there was never follow up that performed the analysis mentioned previously.

Another example of a story told through the episodic frame is CBS13 WOWK's coverage of two officers who were injured at FCl Hazelton in 2018 (WOWK 2018). This story functions in a similar way to WBOY's coverage of Bulger. It explains that two officers were assaulted by an inmate at the prison. The inmate was intoxicated by an unknown substance. The story cites the president of the Local 420 of the American Federation of Government Employees-the same official in the Bulger story-explaining what happened and then commenting that the state 
government needs to help by hiring more staff to work in the prisons. Though this story adds more of an analysis of problems that could be responsible for the officers being assaulted, it does not go in depth on the issue or a potential solution. It mainly describes what occurred and when.

In contrast to episodic frames, thematic frames place an emphasis on the systems, institutions or community cultures that allow for an event to happen. They do not focus on simply explaining what happened to an individual, rather they analyze the circumstances that led to something occurring. According to lyengar (1991), thematic frames focus on broader trends or backgrounds to give a deeper analysis (p. 14). A thematic frame treats the audience as citizens by identifying the shortcomings of a system or government that has led to the problem being reported (Benjamin 2007). Iyengar (1991) found that individuals shown thematic TV reports were less likely to consider individuals than society responsible compared to participants watching episodic TV reports.

Two stories about the Whitey Bulger case employing more of a thematic frame are: one from the Dominion Post and one from West Virginia Public Broadcasting. The story from the Dominion Post raises the question of why Bulger was moved to Hazelton where there were known incarcerated people who had connections to the mafia in Boston where Bulger also had ties (Jenkins 2018). The story from WVPB raises the issue that inadequate prison staff was the reason why Bulger was able to be attacked easily (Mistich 2018). These are thematic because they both report beyond the event that happened and analyze the potential reasons why Bulger was at risk to be murdered. A reporter at the Dominion Post wrote a story about Hazelton's worker picketing to raise awareness on the understaffing issue at the prison. The 
story utilizes the event of employees picketing to explain how the lack of employees in the prison is leading to unsafe and harsher working conditions (Plum 2018). The story also references how the Bureau of Prisons is facing this understaffing issue in a national context, not just in West Virginia.

In contrast to the episodic frame, West Virginia Public Broadcasting's story, “In West Virginia, SNAP Benefits Out of Reach For Drug Felons" utilizes a thematic frame. The story follows Tracy Jividen, a 37-year-old woman who has been incarcerated many times throughout her life for crimes related to substance use disorder. Her voice in the story is used to expose the real life consequences of policies that prohibit her from being qualified for the Supplemental Nutrition Assistance Program, commonly known as food stamps. At the time the story was written, West Virginia still had a policy that prohibited drug-offenders from qualifying for SNAP benefits. To critique the policy and explain its impact, WVPB interviewed two experts, the director of the Sentencing Project, a non-profit in Washington D.C. that researches mass incarceration, and an expert from the The Center for Law and Social Policy, an advocacy organization aimed to improve the lives of people living on low incomes. Following the critique, the story covers how difficult it is for drug-offenders to re-enter society after incarceration (WVPB). This story utilizes the thematic frame to share Jividen's story because it reports on an issue and on the system that allowed that issue to occur. It also reports on legislation that allows people with non-violent felonies and 10 years of a clean record to request that the court reduce their felonies to misdemeanors. "Ban the Box" is another initiative mentioned, that would prevent public employers from asking job applicants about their criminal records (WVPB). 
Another example of the use of thematic framing is from the Charleston Gazette-Mail's 2013 article, "Claims of sexual misconduct at prisons, jails costing state millions." The story was about the state moving all female inmates from 10 regional jails to one of them. It explains that the state had "spent more than $\$ 12$ million over the last decade in court costs, lawyer fees and settlement monies for sexual misconduct claims in prisons and jails" (Harold). It exposed this number and broke down the number of sexual misconduct claims, but it also described the system that had contributed to the rise in sexual assault claims-which included the overcrowding of Lakin Correctional Center and the state's regional jails and the lack of correctional officers to perform the job adequately. As a result of these high numbers, the 260 sentenced females in the regional jails awaiting transfer to Lakin were moved to Tygarts Valley Regional Jail because that was the only jail that had surveillance cameras installed to monitor women and employees (Harold).

The podcast 70 Million utilizes thematic frames in its reporting on jails and prisons across the country. One episode focuses on bail reform in the state of Louisiana and specifically New Orleans. The episode focuses on why the bail industry has become such a lucrative business in New Orleans (Paul 2018). The episode features multiple voices of people who have been arrested and had trouble affording bail. Additionally, it follows a federal class action lawsuit over concerns of one judge setting unreasonably high bail. A thematic frame is used because it analyzes the laws around bail in Louisiana that allow mainly poor people to sit in jail. According to Paul, $97 \%$ of people who post bonds in the state do so through a professional bail bonds service (2018). 
Reveal is another podcast that utilizes the thematic frame when reporting on the criminal justice system. In their series, "And Justice for Some," reporter Al Leston follows stories explaining how the criminal justice system treats people depending on how wealthy they are, their race or gender (2016). In this episode, reporters share a series of stories of people who were forced to sit in jail pretrial, because they could not afford bail. In many of the cases, the offenders were either found not guilty or pleaded guilty simply so that they could leave jail. This episode utilizes the thematic frame because it explains the laws in place that allow for these people to be arrested and it shares the broader context into which several individual cases fit. It treats the audience as citizens and exposes them to the realities of the bail system.

\section{Effects of Episodic vs. Thematic Framing}

Because news is, by its nature, timely and deadline driven, one can see why there might be more episodic coverage than thematic. However, Boorstin (2012) argues that an additional outcome of episodic framing is that there is the possibility for the subjects involved to become heroes or celebrities . A "hero" is defined as a human figure who has demonstrated greatness in some achievement. A "celebrity" is the one in the condition of being much talked about who is known for fame and notoriety. An example of this is from the Charleston Gazette-Mail's coverage of a lawsuit filed by inmates at Alderson against former prison guard Jerrod Grimes, former warden of Prison Camp Alderson Scott Hall and the U.S. government. Grimes was charged with 13 counts of sexual abuse against inmates, and about a dozen stories were written about him and the status of his case, but fewer stories explain how prevalent sexual abuse and assault are in prisons. Yet, each prison and jail has to file regular reports since the passage of the Prison Rape Elimination Act of 2003 because it was considered a big enough 
problem to warrant legislation requiring regular audits (West Virginia Division of Corrections and Rehabilitation).

Oscar Gandy (1994) argues that the effect of journalism favoring the episodic frame over the thematic frame is that episodic framing prevents the audience from critically examining the system with which the individual is interacting for failures or flaws, "traditions in journalism that favor episodic versus thematic frames for stories lead the public toward assigning blame and responsibility to individuals rather than to organizations or institutions. Where individuals are understood to be responsible for their own misfortune, there is no place for a public response beyond punishment" (p. 5).

Depending on the type of frame, the audience can develop ideas about incarcerated people. For this reason, frames are of value to study. Gandy argues that episodic frames could actually do more damage than good for the minorities to whom journalism is supposed to give a voice. According to the Bureau of Justice Statistics, 592 per 100,000 African Americans were incarcerated in 2018 compared to 187 per 100,000 white Americans (Bureau of Justice Statistics 2020). In West Virginia, Black people make up $17 \%$ of the jail population, $12 \%$ of the prison population, but only $4 \%$ of the state population (Vera Institute 2019). Although the rate is the lowest that it has been since the 1990s, it's still alarmingly high. Additionally, the rate of incarceration for men in the U.S. dropped $14 \%$ between $2005-2018$, but rose $10 \%$ for women in the same time frame (Bureau of Justice Statistics). If state media were to favor episodic stories about arrests without deeper analysis, the stories could link race to criminal activity in the minds of an audience, rather than explaining the variables that could lead to those events. 
Coleman (2002) argues that framing crime and violence as a public health issue, which would be a thematic frame according to lyengar (1991), allows for it to actually be prevented and reduced in a society. She writes, ". . . attribution theory says that people in Western cultures typically exaggerate the role of individuals' motives and intentions while downplaying the role of contextual or societal factors" (p. 406). Because of Coleman's theory and nuance of every criminal accusation, journalists must carefully examine how their reporting lays blame on someone in that situation.

In San Marcos, Texas, the state legislature passed a cite-and-release law that would limit the number of people police could arrest for low-level crimes. In 2018, the San Marcos police had an $87 \%$ arrest rate for individuals who could have been cited. After the passage of this law, instead of making an arrest, an officer would issue a citation for crimes like marijuana possession, driving with an invalid license, criminal mischief, graffiti and property and services theft (Osbourne 2020). The San Marcos police already had the option to issue citations instead of arresting people for certain petty crimes, but the data shows that only white citizens benefited from that. Data provided by Hays County showed San Marcos police arrested instead of cited all 72 Black low-level offenders incarcerated in 2018 (Osbourne 2020). If the local papers had run a daily police blotter (a common practice in community newspapers) listing arrests, the list would disproportionately show that more Black people were arrested for criminal activity. Gandy and Coleman make the case that reporting that uses a thematic frame for issues can both foster examination of the systems and promote solutions. 


\section{Solutions Journalism}

Solutions journalism is a genre of reporting that investigates solutions to systemic problems about which current journalists are reporting. Instead of just reporting on an issue, a solutions journalism approach finds people or organizations that are creating solutions to the problem. It's important to remember that solutions journalism is not advocating for a solution to a problem, but rather, it brings the same amount of attention and reporting to solutions as it does to the problem itself (Solutions Journalism Network 2020). A solutions journalism approach can be used in both an episodic and thematic framed story, but solutions stories using a thematic frame are more efficient in addressing systemic issues in communities. Stories that utilize both solutions journalism and a thematic frame focus less on the individuals or case study and more on approaches to change.

In Philadelphia, 15 newsrooms collaborated on formerly incarcerated individuals' reentry into the community called The Reentry Project (Thompson 2018). At the conclusion of the project, the newsrooms had published 200 stories and four short videos about reentry and recidivism in the area. The reporters working on the project traveled to five different states to study how they were dealing with their respective reentry and recidivism issues. In addition to reporting the stories, organizations involved in the project created an app that connects former inmates with mentors, a bilingual website to store information related to reentry services and a forum to discuss the challenges incarcerated people face upon re-entry because their examination of the system revealed common problems that many incarcerated people face upon reentry (Thompson 2018). 
One example of a solutions-oriented story from the project is from the Philadelphia Inquirer. The story examines whether a community bail fund can actually reduce the number of incarcerated people in the city (Melamed 2017). The story follows Carlette Golden, a woman who sat in jail for 14 months without knowing what crime she was being charged with. Eventually, she was released, after organizers with the Philly Community Bail Fund, raised enough money to pay for her bail. The story itself examines how the fund, and others like it, are some of the only ways for poor people to get out of jail as they await their trials. This is a solutions story that utilizes a thematic frame because it focuses on an individual, but also analyzes the bail system at a more broad scale. It opens with Golden's story, but the majority of the story focuses on community bail funds being the main source of funding for many people in jail.

A thematic framing example of solutions journalism from The Reentry Project comes from a partner newsroom WHYY, the PBS/NPR affiliate in Philadelphia. This story highlights activists in the Philadelphia area who are raising funds to pay the bail of those who cannot afford it. JoJuan Powell was arrested after authorities did not believe her claims that she broke up a physical altercation that happened outside her home. A judge set her bail at $\$ 2,501$ and Powell, a lunch lady making $\$ 10.50$ an hour, would have had to save up a number of paychecks before she could have paid it. A number of activist organizations participated in "National Momma's Bail Out Day," where they raised money to pay off multiple women's bail charges. Powell's story is interwoven with information on how bail functions and on organizations that have offered potential solutions to the problem. Following the data on bail in Philadelphia, the story presents the ways in which city council members are addressing the issue, how 
organizations like Black Lives Matter Philadelphia and \#No215Jail coalition are raising money and awareness to put an end to cash bail.

As Coleman suggested about the effect of thematic reporting generating solutions, the reporting from The Reentry Project resulted in the creation of Resolve Philadelphia which "develops and advances journalism built on equity, collaboration, and the elevation of community voices and solutions" (Resolve Philadelphia 2020). This organization is a collaboration between 20 newsrooms that are reporting on communities and working to solve pressing local issues. According to Resolve's website, the editorial team coordinates events including info sessions with employers to discuss challenges formerly incarcerated people face in the job search process and hackathons to help develop tech resources for people experiencing poverty. These organizations are two examples of solutions journalism that assess potential solutions to pressing local and national problems.

The Women Beyond Bars project is an example of journalism that has used a lens of solutions journalism in coverage of incarceration in West Virginia. Beginning in 2018, a team of students began covering the issues that had been affecting incarcerated women particularly. While a reporter with the project, my reporting specifically focused on alternatives to prison and the overcrowding of the state's only female prison, Lakin Correctional Center, as well as the state's 10 regional jails. (Orsagos 2020). This project has influenced the root of my research in the criminal justice system, and it has contributed to a state-wide conversation around justice reform. However, there's more work to be done on the topic, covering incarceration issues with a solutions journalism lens. 
In 2015, the West Virginia state legislature passed SB 371, commonly known as the Justice Reinvestment Act (Orsagos 2018). Since its implementation in 2015, West Virginia has spent more than $\$ 11$ million dollars on programs designed to help reduce the incarcerated population in the state and to reduce recidivism. Each year, money is allocated in the state's budget that is sent to programs that offer alternatives to prison, such as recovery programs for substance abuse disorder, or for victims of domestic or sexual violence. The solutions aspect of the story reports on the bill and examines whether or not it has been effective in reducing the incarcerated population. The findings show that it is actually too early to tell if Justice Reinvestment is reducing the number of people incarcerated because of a lack of comprehensive data. Since JRI is meant to reduce recidivism, there's a need for up-to-date recidivism rates, however the state tracks recidivism by measuring if and when someone returns to jail or prison within three years of their initial release. So, in August 2019, the state published a study on the recidivism rate since 2015 , tracking people who were released from prison in the 2015 calendar year, which was the first year of JRI spending. The solutions lens exists in this story because it covers the issue at hand, the high number of incarcerated people in West Virginia, and a proposed solution to that problem.

The Women Beyond Bars project also includes stories on drug court, the KIDS program for mothers at Lakin, restorative justice and bail reform in West Virginia. In the wake of the coronavirus pandemic, jails and prisons have become an epicenter of conversation regarding human rights issues because of the increased risk of contracting the deadly disease while incarcerated. Because of this, there is an even greater responsibility on journalists to report on potential solutions to programs related to the overcrowding of prisons and jails. 


\section{Research Questions}

Media research suggests that a thematic approach to crime and justice reporting promotes greater understanding of this complex system and its impact on various members of a community. Unlike episodic coverage of the justice system, a thematic frame focuses less on a specific individual or subject. Instead, it uses an individual in cooperation with analysis of the greater landscape of the situation or problem. Focused reporting on solutions illustrates "real struggle in social change" by "going beyond inspiration to provide evidence and insights about how social change really works" (SolutionsU). A solutions journalism approach to justice reporting does more than present the issue at hand. It searches for proposed solutions to that issue and analyzes its effectiveness. It follows that a solutions journalism focus using a thematic frame would be the preferred approach if a reporter wanted to explore issues that arise from mass incarceration in West Virginia and invite the audience to understand why the state incarcerates so many people, how much it's costing the community and explore solutions people are putting forward.

Initial Research Questions:

RQ 1: How can a thematic frame be applied to justice reform reporting (the problem of mass incarceration) in a way that engages audience interest and investment in a complex system like bail reform?

RQ2: How can a solutions journalism focus be applied to justice reform coverage in a way that faithfully evaluates a solution without advocating for it? 


\section{Methodology}

The following section explains the structure and organization of the project. It argues why the podcast is the best medium for the project and the theoretical framework used. The podcast series explores a recent bill passed in the West Virginia state legislature that encourages judges to release people accused of certain, nonviolent offenses out on personal recognizance bonds rather than force them to wait for their trial in jail.

\section{The Issue}

Using a thematic framing approach combined with a solutions emphasis, the project explores an issue that identifies the problems in the system that have led to issues like overcrowding and poor health services in the regional jails.

In 2020, $\underline{\text { House Bill } 2419}$ was passed in the West Virginia legislature allowing judges to forgo bail and allow certain nonviolent offenders out of jail on their own recognizance (2020). It was introduced in the state legislature with the hope of reducing the prison and jail populations in the state, according to the Charleston Gazette-Mail, in a series of stories that reporter Lacie Pierson wrote (2020a). “People would qualify for a personal recognizance bond if they're charged with certain misdemeanors that don't involve violence, a deadly weapon, a minor, a drug crime, crimes of a sexual nature, a traffic crash causing injury or death, or receiving and transferring stolen property worth more than \$250" wrote Pierson (2020a). The bill passed around the same time that Pierson was reporting that eight of the state's 10 regional jails were over capacity (Pierson 2020b). At the time the article was published, there were 4,265 beds available at regional jails, and 5,168 people incarcerated (Pierson 2020b). In both of her stories, 
Pierson reported on the issue at hand, the HB 2419, and presented the argument for why the bill was put into place.

Coverage of the bill from West Virginia Public Broadcasting was similar in the sense that the focus of the story is on the bill, but not as much on the parties who would be affected by it (Allen 2020). This story explained the purpose of the bill and recounted opposing state legislators' views on it. Though the story talks about political opposition to the bill, it does not specifically utilize a solutions lens. It addresses the fact that in January 2020, the state's 10 regional jails were $19 \%$ overcapacity and that almost half of the people in jail were waiting on trial and had not yet been charged with a crime (Allen 2020). An interesting point that Allen made that Pierson did not was that the bill would require "judges and magistrates to give "the least restrictive bail conditions determined to be reasonably necessary to assure appearance as well as ensure the safety of persons in the community and maintenance of evidence'" (Allen 2020).

Neither Pierson nor Allen went into detail about how the legislation was received by various members of the state's justice community, how it would affect the court system, how it was supposed to be implemented or within what time frame. The subject is dense with data, numbers and a population that is traditionally underrepresented in media, so helping people to understand why this is significant to them is going to be important from the beginning.

\section{The Podcast Medium}

As the digital age of journalism has expanded over the last decade, podcasting has increasingly developed as a space for investigative journalism. A podcast has advantages like an increased intimacy for listeners, the ability for the listener to listen on their own time and for 
reporters to show more of their own personalities through their voices. Dowling and Miller (2019) argue that the evolution of streaming-era media has led to increased success for the podcasting genre. It also allows for more "experimentation in reporting and storytelling for thought-provoking documentary narrative[s]" and long form content known as "deep dives" (p. 3). This makes the medium especially suitable for a thematic approach to a complex issue with multiple peoples' stories.

Podcasts offer a unique experience for the producer to share an in-depth and intimate story with listeners. Scardina (2018) says that podcasts "layer the nostalgia of a radio show into the contemporary fabric of digital media." Viewers have complete control over when and where they decide to listen and for how long they want to. Instead of following a regular show schedule, podcasts offer the audience the freedom to listen at one's own pace. One study found that $80 \%$ of listeners use their mobile devices to listen to podcasts, there's an added layer of personal experience connected with podcasts (Chan-Olmsted 2019). Audio also allows for a very intimate experience for the listener because of the closeness of the reporter's and interview subject's voice. One study found that listeners want hosts who are "authentic, feel like a friend, and share the user's beliefs" (2019). The average podcast consumer listens to about four podcasts per week for around 30 or 60 minutes (2019). According to Delmar (2016), the average student loses concentration after 20 minutes of a lecture. In addition to loss of concentration, Delmar says that the average podcast should be no longer than 22 minutes (2016). In medical podcasting, Cosimini, Cho, et al (2017) found that $10-15$ minutes is the most optimal time for an educational podcast. 
A podcast is the best medium for this project because of its ability to connect the complex policy to real people whose voices and personalities will come through in the recordings. It will allow the podcaster to speak in a more personal tone which will be beneficial when breaking down a complicated system like bail. "Unlike stories produced for screens where emotions are acted out in visual form, audio stories explore our lives through sounds and spoken words, intimately whispered into our ears," writes Lingren (2016) about the nature of podcasts.

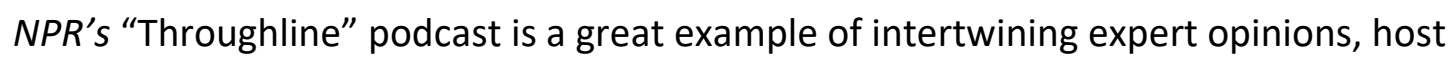
commentary and a wide range of engaging audio. In the episode, “ Incarceration", the hosts of the podcast interview experts about the history of incarceration in the country, as well as share their own experiences visiting the country's first penitentiary outside of Philadelphia (Abdelfatah, Arablouei 2020).

Another podcast specifically covering the justice system is called "Justice in America" from The Appeal. In episode one of the series, "Justice for the Rich, Money Bail" the hosts explain how the money bail system operates in the country and how it primarily affects poor, uneducated and people of color (Duffy Rice, Smith 2018). This podcast, which is 51 minutes long, has more than 15 minutes at the beginning explaining the basics of the bail system so that audience members are able to understand. It has more opinion than news, but it does an excellent job of explaining a complicated system in a way that keeps the listener entertained and engaged.

Another episode from 70 Million titled "How Bail Shackles Women of Color" goes deeper than just explaining the effects the bail system has on those incarcerated (Kirkland 
2019). The episode explores the effects of women who often have to carry the load of the family once their spouse or father of their children becomes incarcerated. This episode offers a different perspective that is not commonly covered in stories on the justice system. It utilizes the voice of public defenders who work with people in the bail system as well as women who are struggling to support their significant other incarcerated and their family on the outside.

\section{Creating the Podcast}

The podcast in this methodology examines the bail reform bill that passed in West Virginia in March 2020. It explains the bail process, examines who the new policy affects and who benefits from it and explores the value of the proposed solution to the problem of mass incarceration and possible consequences of that proposed solution.

The four-part series reports on the passing of this bill with regard to its impact on the court system and jail population in West Virginia. The approach to this complex topic is grounded in personal stories, to engage listeners emotionally, supported by data and information about the justice system to give people a full picture of the landscape. The podcast utilizes a 15-20 minute time frame to keep listeners actively engaged and focused on the subject. The podcasts listed in the section above range from 40-60 minutes, but are wholly contained with regard to their subject matter. This podcast looks at bail reform from a variety of angles and leaves people at the end of each episode with questions that will be answered in the next one.

The series will be produced for publication with West Virginia Public Broadcasting. Glynis Board, a member of the committee for this project and the assistant news director at 
West Virginia Public Broadcasting will also serve as an editor and liaison with WVPB to facilitate state-wide publication.

\section{Questions Guiding the Series}

Some of the questions that guided reporting in the podcast were:

1: Who does this reform primarily affect (incarcerated people, judges and court clerks, bail bonds industry)?

2: In the past, how have high bail prices contributed to the overcrowding of regional jails in the state?

3: How does the overcrowding of jails affect the average West Virginian?

4: Is bail assessed evenly among race and genders in West Virginia?

5: How much money from bail does the state receive and where does that money go? 6: Where is the state in the implementation process of HB 2419? What are the factors involved?

7: West Virginia is one of several states trying to work on bail reform (California, New York, Oklahoma, Louisiana). How is the process going in those states that have already implemented it? What is working and what has not worked?

These questions will be examined in a series of 4-5 thematic podcasts covering bail reform, in which the audience will get to meet justice involved stakeholders in West Virginia.

\section{Themes for Each Episode}

Each episode explored the questions listed above. The themes examined are:

1. An overview of the reform and reasons for the legislation. This episode sets up the conditions and issues that led to the legislation for bail reform. It examines overcrowding in 
jails, the cost of incarcerating people in jails, the prevalence of people in jails who live in poverty as well as background on who proposed the legislation and why. People interviewed for this episode include a person who was unable to pay bail, a person advocating for reform, one or more of the legislators who proposed the bill and a representative of West Virginia's Division of Corrections and Rehabilitation (see appendix A and B for more extensive notes on each episode and potential interview questions).

Episode one sets the tone of the podcast, as well as highlights future episodes to encourage the listener to continue to listen. It explains the basics of the bail system and the nature and background of the current landscape of regional jails in the state. This episode includes demographic information about people in jails including gender, race, age, economic status and mental health status.

In an in-depth report on the number of actual U.S. jail deaths, Reuters (2020) reported that among the 500 jails investigated, West Virginia's 10 regional jails had the highest death rate and more than 50\% above the national average (So). This episode introduces the criticism that the new legislation doesn't necessitate any change from the previous system, and teases the next episode. The bill says, "House Bill 2419 requires judges and magistrates to give "the least restrictive bail conditions determined to be reasonably necessary to assure appearance as well as ensure the safety of persons in the community and maintenance of evidence" (West Virginia Legislature). In some instances, that can include releasing a pretrial defendant without bail. But how does the judge determine what is the least restrictive required?

2.Where is the state in the process of implementation now. What has happened since the legislation passed? How much has changed? Who has the power to implement that 
change? How has the COVID-19 pandemic affected this? This segment includes a discussion of the state releasing nonviolent offenders for reasons related to the COVID-19 pandemic (De La Cruz, et al. 2020). Potential interview subjects include a representative of legal aid who assists people in the process, a judge who hears misdemeanor cases and decides bail, a county clerk or a public defender who can speak about bail reform, and a person, who is no longer incarcerated, but who paid bail or was released on recognizance since the legislation passed.

3. Who opposes bail reform? This episode looks at people who have reservations about letting people out of jail on their own recognizance and possible fallouts. Interviewees should include a representative of the bail bonds industry, a person who opposes bail reform out of fear of continued criminal activity and state legislators. Is there an economic impact from the elimination of bail? Before the passing of HB 2419, how much money did the bail system generate? Where did the money go and what was it used for? Will taxpayers actually see a difference with the implementation of HB 2419? Potential interview subjects include a bail bonds person who could speak about the impact of the bill on their business, the state legislators who opposed the bill, a data analyst focusing on criminal justice in West Virginia to speak about the ways bail impacts most poor and uneducated people and how much money bail actually brings into the state.

\section{How is bail reform going at other places in the country, and what could that mean}

for West Virginia? This episode reports on what other states that incarcerate a large number of people are doing to address bail reform. California, New York, Oklahoma and Louisiana are all states addressing it in different ways. California and New York are doing away with cash bail, how is that going? Oklahoma incarcerates the most women in the world, but the state is not 
necessarily using policy to reform bail, however other nonprofits are stepping up to address the problem. Kentucky began using a validated pretrial risk assessment tool in 2013, and in 2017, the state began allowing release to low-risk offenders without an appearance before a judge. In addition, a statewide pretrial service agency is required to make a release recommendation within 24 hours of arrest, and reminds people of upcoming court dates via automated texts and calls (Herring 2020). This episode also ties in how the reforms in other states could impact West Virginia, if those same ones were made in the state. Potential interview subjects for this episode should include employees at bail-related non-profits in Oklahoma and Louisiana, legislators or bail reform advocates who can explain legislation in California and New York, detractors of the legislation passed in those same states, legal aid lawyers in West Virginia and legislators who sponsored the bill.

\section{Analysis}

“\$50,000 to Freedom: Exploring Bail in West Virginia" was published on West Virginia Public Broadcasting's website between August 2 and August 23, 2021. It is a four episode podcast with each episode lasting between 12 and 18 minutes. The podcast in its entirety was published on the web chronologically after it was introduced each Monday on "West Virginia Morning" radio show. What follows is the production chronology for the podcast.

A note about the limitations of the initial question:

Here are the analytics available regarding the audience's engagement of the series online to date.

1. The fourth episode had the highest engaged minutes with 25 minutes. 
2. On August 24,2021 , the three episodes measured had 99 engaged minutes (713 minutes during the entire month), 137 page views (912 during the month) and an average engaged time of 43 seconds ( 46 seconds during the entire month).

3. The traffic source of the fourth episode, which had the most engagement on the website, was split evenly amongst searches through social media, web search and internally on wvpublic.org.

4. On the reporter's personal Twitter page:

a. The first episode received 4,240 total impressions, 84 engagements, four retweets, one quote tweet and 18 likes.

b. The second episode received 1,486 impressions, 21 engagements, one retweet, one quote tweet and four likes.

c. The third episode received 443 impressions, 11 engagements, one retweet and three likes.

d. The fourth episode received 306 impressions, one engagement, zero retweets and zero likes.

However, the initial exposure to the podcast was through radio, and the episodes were shortened to fit the time limits of the show. There are no analytics that measure if that audience was active or passive. Each episode was posted on WVPB's Twitter and Facebook once, but there was no extended plan to promote the podcast. Navigation to the podcast isn't promoted anywhere else on the website, so it is more difficult for the audience to find it. Also, each episode was posted separately online and were not linked together. For these reasons, the initial research question was not suitable for this project, but how I applied it and what the 
strengths and weaknesses of my application of the question can be measured. I evaluated the thematic frame to include overcrowding in jails, the fiscal costs of incarceration, stakeholders in the state's legal justice system, the court system and the corporate bond industry.

\section{Chronology}

Upon the successful completion of the project proposal in late December 2020, the next step was beginning with interviews and piecing together each episode of the podcast. Interviews began at the end of January 2021 and continued throughout the month of March. There were 19 official interviews conducted and numerous emails and phone calls to complete interviews for background information and other pre-interview meetings (more detailed notes on interviews with lawyers, legislators and formerly incarcerated people can be found in Appendix D). Each episode was edited throughout the months of April and May, and the editing process took place in May, June and early July (episode production notes can be found in Appendix E). The podcast was published in early August and was sent to the committee on August 19.

\section{Publishing}

The podcast was published on West Virginia Public Broadcasting's website in late July and early August of 2021. In addition to the audio pieces, the episodes also featured a web version as well as photos of some people interviewed in the series. This project was an appropriate fit for WBPB's style and audience. The media outlet's motto is: "Telling West Virginia's Story." Publication on WVPB facilitates the series' distribution to a large number of people who may be interested in the criminal justice system in West Virginia as well as to those who pay the taxes that fund the system. 


\section{Discussion}

This section will return to the proposed questions in the initial project proposal and attempt to address them based on reporting, research and interviews conducted after the production of the podcast. The podcast utilized a thematic frame to explore the criminal justice system through the lens of bail, so the audience could develop a more comprehensive understanding of how the bail system in West Virginia contributes to the problem of mass incarceration. It also evaluated the efficiency of a piece of legislation, as a solution to bail reform.

\section{Who does this reform primarily affect (incarcerated people, judges and court clerks, bail} bonds industry)?

Now that it's completed, the question to ask is who does the bail system primarily affect and how could reform help those people? HB 2419, the legislation analyzed in this project, does not seem to help any of the parties involved: incarcerated people, judges and court clerks or bail bondsmen. When changing the question to who does the bail system primarily affect, the answer becomes clear and that is people living in poverty. Attorney Devon Unger said that the way in which the bail system currently operates, those who do not have assets to offer to the court are the ones most affected:

"I mean, it's poor people, it's people who just do not have access to, you know, cash or credit or property. You know, these are the ones who you know, cash bail effects because if you have money, if you have property, if you have resources, you know, you're able to meet the requirements and get out of jail. So, you know, cash bail really only impacts poor people. I mean, frankly, that's the long and short of it." 
The majority of participants interviewed for this project spoke about how quality legislation could really help the people who are currently in jail pretrial. A crucial question for legislatures and judges to ask themselves when they are assessing how they could reform the bail system. Without considering it, the likelihood of it helping those people becomes slim.

\section{In the past, how have high bail prices contributed to the overcrowding of regional jails in the} state?

Because the state criminal justice system lacks this data, the podcast was adapted to explain this problem. In the second episode, it's made clear that it's difficult to measure the extent of the impact of bail and pretrial detention because of the lack of data. Data showing how high bail prices have disproportionately impacted people living in poverty doesn't exist. Currently, no one working for the Division of Corrections and Rehabilitation keeps track of which counties have done a better job implementing HB 2419 or which magistrates or judges in each county are enforcing the law. Data collection at the county level is sparse too. Multiple Freedom of Information Act Requests to five counties (Monongalia, Kanawha, Raleigh, Braxton and Cabell Counties) asking for specific information regarding the number of persons arrested and charged with a crime in the month of August 2019 (before HB 2419 passed) and July 2020 (after the law was enacted). For each person for the charge, the demographic data of the defendant, conditions set for pretrial release, whether a follow-up hearing was held within 72 hours for defendants unable to meet the requirements of a secured bond, the results of the hearing, the name of the magistrate or circuit court judge and the arresting agency were also requested. Each county responded and none of them collected the data requested. 
Quenton King, criminal justice policy analyst at the West Virginia Center on Budget and Policy said criminal justice reform bills have little impact in areas where there isn't a lot of data collection. Rayna Momen, a doctoral student who teaches undergraduate level sociology courses inside prisons, had similar beliefs about the lack of data. They said that the lack of data in the state's justice system makes it that much more difficult for advocates to lobby for reform because there is little data to backup anecdotal accounts from incarcerated people. This lack of data is mentioned throughout the entire series, but most explicitly in episode one and episode two.

\section{How does the overcrowding of jails affect the average West Virginian?}

Human rights concerns are an obvious issue, which are touched on in episode one when Lisa Hartline's experiences while incarcerated in North Central Regional Jail are shared. Hartline explains her jail pod was overcrowded, she would be outside for only one hour per day, concrete floors and walls make the room very cold, etc. Also mentioned in the same episode is data from Reuters that reports West Virginia jails had the highest death rate of the 500 jails studied. The overcrowding problem also affects every West Virginian because those are the taxpayers who are paying for the jails to stay afloat. According to a report Quenton King published in January, it costs about $\$ 50$ per day to house someone in a regional jail. When the jails are overcrowded, that much more money is needed to support those people. Additionally, counties are responsible for paying for the incarcerated people from their counties. Currently, almost two out of every three counties in West Virginia are unable to pay their regional jail bills. 
As the daily jail price is set to increase within the next year, more money will be allocated to fund it.

\section{Is bail assessed evenly among race and genders in West Virginia?}

There were intentions to touch on this question in the podcast, but only it was only referenced in regard to other states. It's an area that could have been expanded upon in the series. The data that is available on race and gender is sparse. But on July 14,2021 , Black people made up $13.1 \%$ of the DCR population while white people made up $85.4 \%$ of the population, according to data from the DCR. Data from the Vera Institute of Justice says that in 2015, Black people made up $17 \%$ of the jail population and only $4 \%$ of the state population (Incarceration Trends in West Virginia). In the same year, white people made up $80 \%$ of the jail population and $93 \%$ of the state population. This information would have been useful to include in episode one, when human rights issues inside the jails were mentioned. Racial disparities in jails are briefly explained in episode four when speaking with Anthony Body of The Bail Project and Alex Shalom of the ACLU of New Jersey. Body mentions that there is a disproportionate number of people of color incarcerated in Cuyahoga County and Shalom says the New Jersey bail reform bill has helped to release thousands from jails, they still remain disproportionately filled with people of color. With regard to gender, there were 6,944 fewer incarcerated women than men on the same date in jails in and prisons, according to data from the DCR. This information was not included in the podcast because pretrial data was the main focus. There was no data found to explain how bail was assessed in conjunction with race or gender. 
How much money from bail does the state receive and where does that money go?

When an accused person is assigned bail, they are more than likely paying a portion of that fee to a corporate bondsman if they can't afford it. People who are accused who pay their bail up front, receive the money back after all their court appearances, minus court fees. David Bourne, spokesperson for the Professional Bail Agents of the United States said he believes there should be a cap on bail where the lowest possible is $\$ 2,500$ and the highest is $\$ 10,000$. However, lawyers like Devon Unger and policy analysts like Quenton King say any kind of monetary bail mainly impacts people living in poverty because they don't have the means to pay to be released.

Where is the state in the implementation process of HB 2419? What are the factors involved?

The lack of data in the state's criminal justice system makes it difficult to answer this question. HB 2419 does not require any sort of data collection, so there is no way to tell which counties are enforcing the law more than others or which judges or magistrates in each county are enforcing the law. So rather than turn to data about court case outcomes, the podcast follows the jail numbers for numerous months after the law went into effect to help the audience draw its own conclusions about how successful the law is in fulfilling its purpose. Bail reform in West Virginia is in a state of limbo because of how loosely the law is written. Episode two investigates how the law is written and how it does not actually help to reduce the overcrowded regional jails. 
West Virginia is one of several states trying to work on bail reform (California, New York,

Oklahoma, Louisiana). How is the process going in those states that have already implemented it? What is working and what has not worked?

Research was compiled on bail reform in Illinois, California, Pennsylvania, Ohio, Kentucky and New Jersey. Ohio, Kentucky and New Jersey were the only states to respond to my inquiries, but a lot of information about how the bail system has been reformed in those states was used in the series. Kentucky uses a program called administrative release, where a person accused of a nonviolent, nonsexual misdemeanor and certain low level felonies will not stand before a judge at an arraignment. Instead, they will be automatically released and must return for their trial. The program was expanded as a result of the COVID-19 pandemic, but began to relax beginning in 2021. In Ohio, the audience meets Anthony Body, a bail disruptor for The Bail Project office in Cleveland. He serves clients currently incarcerated in the Cuyahoga County Jail and connects them to service providers in housing, substance use disorder treatment, mental health services and transportation services. He also is able to post bail for them on behalf of The Bail Project. In 2017, New Jersey completely reformed the bail system from one that was based on monetary resources to one that was based on perception of risk. Now, when someone is cited in the state, the police officer can either issue the person a summons - which is essentially a ticket—or arrest them and take them to jail. The person then must stand before a judge within 48 hours to decide a spectrum of decisions beginning with release on personal recognizance and, at the worst, deciding detention.

Bail reform in some of these states is affecting more change because the laws are written with more specific prescriptions for change in dollar amounts and required actions by 
the magistrates. In the case of New Jersey and Illinois, the system was completely abolished and another was created to ensure that there was drastic change in the way bail worked. In addition to the previous seven questions which guided reporting for the podcast, the initial proposal included the following two questions with regard to the theoretical framework for the project.

RQ 1: How can a thematic frame be applied to justice reform reporting in a way that engages audience interest and investment in a complex system like bail reform?

This was the initial research question asked at the beginning of the reporting. However, upon review, a better research question allowing more analysis of actual experience would be: How can a thematic frame be applied to justice reform reporting on a complex system like bail? Upon evaluation of those topics, one may argue a thematic frame can be applied to justice reform reporting in an audio storytelling format as long as it presents characters and stories to help the audience understand the human impacts of the subject being reported. A thematic frame analyzes a problem through the circumstances that allow that problem to exist (lyengar 1991). The thematic frame used in the series presented the landscape of issues that are responsible for legislation like HB 2419. Those issues include jail overcrowding, a number of counties unable to pay for jail bills and the COVID-19 pandemic. But the information on the nuts and bolts of the justice system can be very dry, and the podcast quickly returns to a human story after no longer than three or four minutes in any episode. Each of the following episodes extrapolate the law, explaining the successes and failures of it and how it has or has not 
remedied any of the issues. Having engaging voices like Lisa Hartline, Quenton King, Staci Kisner and Anthony Body make the subject more digestible and relatable.

It's also important to note that the expansiveness of the factors responsible for mass incarceration are abundant, and so, this project used a thematic frame to explore one solution to mass incarceration, which was the bail system. By choosing to explore the bail system, the reporter indefinitely leaves out other areas of the criminal justice system that allow for mass incarceration to exist. A portion of the audience may interpret this as a bias of the reporter because it's not possible to examine all the facets to mass incarceration. For this reason, it may be easier for journalists to report using an episodic frame to avoid this problem.

RQ2: How can a solutions journalism focus be applied to justice reform in a way that faithfully evaluates a solution without advocating for it?

In order to look at bail reform in West Virginia using a solutions journalism approach, which examines a particular solution to the problem being reported on, multiple perspectives on each side of the conversation were shared. Voices from the pro-reform side like Lisa Hartline, Quenton King and Devon Unger were shared while also giving the same time to voices who think differently like Staci Kisner and David Bourne. To evaluate the podcast, it was presented to WVCBP's Quenton King, Delegate Brandon Steele, who voted against HB 2419 and Staci Kisner, the owner of Bill's Bail Bonds. I asked them to respond to five questions, which include:

1. What are your initial thoughts now that you've listened to the entire podcast? 
2. How fairly do you think I presented various sides of the argument for and against bail reform and HB 2419?

3. On a scale of 1 to 10 , with 1 being fair and balanced journalism and $\mathbf{1 0}$ being advocacy, where do you think my reporting stands?

4. What angles do you think I missed with regard to HB 2419, bail reform or the justice system in West Virginia?

5. What things do you think I did well in my reporting?

\begin{tabular}{|l|l|l|l|}
\hline Questions & $\begin{array}{l}\text { Initials thoughts on } \\
\text { the series }\end{array}$ & $\begin{array}{l}\text { How fairly were both } \\
\text { sides of the } \\
\text { argument } \\
\text { presented? }\end{array}$ & $\begin{array}{l}\text { On a scale of 1 (fair) } \\
\text { to 10 (advocacy) } \\
\text { where does the } \\
\text { reporting in this } \\
\text { project stand? }\end{array}$ \\
\hline Quenton King & $\begin{array}{l}\text { An earlier publishing } \\
\text { time. }\end{array}$ & Fairly & 2 \\
\hline $\begin{array}{l}\text { Delegate Brandon } \\
\text { Steele }\end{array}$ & $\begin{array}{l}\text { He was disappointed } \\
\text { and called it } \\
\text { "complete advocacy." }\end{array}$ & $\begin{array}{l}\text { Bias toward pro- } \\
\text { reform participants. }\end{array}$ & $\begin{array}{l}10 \text { (complete } \\
\text { advocacy) }\end{array}$ \\
\hline Staci Kisner & $\begin{array}{l}\text { Thought it was very } \\
\text { good }\end{array}$ & Fairly & N/A \\
\hline
\end{tabular}

Quenton King's responses were overall positive. He said he enjoyed the range of perspectives presented, but wished the podcast was published before the state legislature amended the bill that extended the time for a follow up hearing. He also would have liked to hear more about why Delegate John Shott was so interested in this kind of bill, his thoughts on its effects since its implementation and more about how bondsmen fought the bill when it was being debated in the legislative session. It's important to note there is audio from Delegate Shott explaining why he believes these kinds of bills are important, but the episode was dense after explaining the bill itself. There wasn't space to add more of Delegate Shott's views without 
making the episode more complicated. The Association of West Virginia Bail Bondsmen declined multiple interview requests.

Delegate Steele's, who was opposed to the bail reform law, responded quite differently. He was rather disappointed in the podcast, saying that it was "complete advocacy." One of his main complaints was that there are too many individuals from the American Civil Liberties Union and the West Virginia Center on Budget and Policy. He also asserted that by covering the way bail was reformed in other states, I was making the assumption that the same problems exist in West Virginia:

"The most disappointing part was the use, in episode 4, of colloquial accounts of racial disparity in incarceration in Ohio and New Jersey. The WV ACLU, WV Innocence Project, and Center for Budget and Policy made no mention of racial disparity in WV incarceration. Neither did the other individuals interviewed, such as bail bondsmen. The inclusion of these statements from Ohio and New Jersey falsely implies the problem exists in WV."

Delegate Steele has a fair critique that there are more pro-reform advocates who are featured in the podcast. It was very difficult to gain trust from people who are against bail reform. The delegate also asserted that episode four falsely implies a racial disparity in the state's jails. There isn't a place in episode four where that claim is asserted, but there is a racial disparity in the state's jails. According to data from Vera Institute of Justice, in 2015, Black people constituted $4 \%$ of the state's population, but $17 \%$ of the people in jail (Vera). This revealed a hole in the reporting that could have received more space in the podcast. Steele was 
also unhappy that only one soundbite of our 30 minute interview made it into the podcast.

Delegate Steele only spoke briefly about his thoughts on HB 2419 while the rest of the interview he discussed broader topics in the criminal justice system. His final critique seems to more broadly say that the thematic frame approach was not thorough enough. Reforms to the bail system was the only solution looked at in this approach, and by doing so, it's possible the reporter appears to have a bias. He raises the question of whether or not it's possible to adequately look at all the angles of the justice system that give an outsider a complete idea.

Staci Kisner, the owner of Bill's Bail Bonds had some positive remarks about the podcast. She did not answer any of the questions that sent to her for response, but she said that she thought it was very well done. She said that I covered the subject well and let multiple sides of the argument be aired throughout each episode.

The series is a powerful example of how personal stories can help an audience understand the impacts of a complex and intricate topic like bail. It meets general standards for a thematic frame by its broader scope of exploration around the topic of bail. It does this by not just reporting on HB 2419, but on how the bail system works in the state, who the law is affecting and how it is being implemented. However, it does expose the difficulties of using a thematic frame approach on a subject like mass incarceration. Because the problem of mass incarceration is so expensive, the use of the thematic frame will ultimately leave out another factor to the problem. By doing this, it could lead an audience to believe that the reporter has a bias. In the instance of this project, by choosing bail reform, some believed that the reporter was biased toward reform. This could be a reason why it is easier for journalists to use an 
episodic approach because there is less risk of ignoring a factor of the problem because there is not as much in-depth analysis.

\section{Self-Assessment of the Project}

I began this project under the assumption that there would be a clear line between proreform and anti-reform people, however, as I continued meeting with people whose ideas landed across the spectrum, I realized that was not the case. The majority of people on both sides of the argument believe that there are too many people in West Virginia regional jails and that the bail system disproportionately affects those living in poverty. The only difference between the two parties is how to go about reforming the system. Those who advocate for the abolishment of the money bail system tend to pair that idea with a complete transformation of the way the criminal justice system currently operates. Quenton King is in favor of the abolition of the current criminal justice system. Lawyers like Devon Unger say that the money bail system needs to be completely abolished. The people who push back on those calls for reform tend to believe there is a way to make positive change without completely destroying the current system. For example, David Bourne, the spokesperson for the Professional Bail Agents of the United States thinks that there should be a cap on cash bail with $\$ 2,500$ as the minimum and $\$ 10,000$ as the maximum. In his view, if more than $\$ 10,000$ is needed to assure public safety then that person should probably not be allowed out of jail. Staci Kisner believes that if the money bail system were abolished, the courts would have too much power and citizens would have less control with regard to pretrial release. 
Either way, the biggest lesson I've taken from this project is that there is not one, right answer. Where states that have made dramatic changes, they were done so with precise consideration and a number of resources that West Virginia has not dedicated to its justice system. In New Jersey, Chief Justice of the Supreme Court Stuart Rabner assembled an entire team of prosecutors, defense attorneys, advocates, judges and bail bondsmen to draft changes to the bail system outside of legislation. That is how the state's reform came to be. In Ohio, the Supreme Court created a committee similar to that of New Jersey to produce a report about the way bail functions in the state and who it primarily affects.

Lastly, I leave this project with a greater understanding of the power of storytelling in journalism. I believe that there is immeasurable potential to encourage an audience to think about complex issues by finding the right stories to pair with them. It was difficult to explain the bail system and HB 2419 in an attention-grabbing way in the podcast format, but I am confident that the storytelling I brought to this project aided in the explanation of this complex system.

\section{Limitations and Suggestions for Future Research}

A significant limitation of this project was the various distances of the interview subjects from my Morgantown apartment. The subject of the project demanded input from a number of individuals from all around West Virginia and outside of the state. In West Virginia, I

interviewed people from Charlestown, Charleston, Martinsburg, Bluefield and more. Outside of the state, I had interviews with individuals in Pennsylvania, Ohio, New Jersey, Kentucky, Washington D.C. and New York. On top of these locations, the COVID-19 pandemic forced many people to refrain from in-person interviews and resort to Zoom interviews or ones completed 
over the phone. This created another challenge for me because I was unable to get natural sound from as many interview subjects as I would have liked. I was able to do an in-person interview with each of the main voices in all episodes except episode four.

I had a lot of difficulty making contacts outside of West Virginia. I didn't get a lot of cooperation from representatives of organizations and government entities for participation in interviews. The result of this was that I had too many voices in the series from organizations like the ACLU and other policy and advocacy organizations.

Another limitation of this project is the variety of formerly incarcerated people who were included on the podcast. I met multiple people who were incarcerated pretrial solely because they could not afford bail, but they did not want to share their stories on the podcast. My original plan was to have a different voice from a formerly incarcerated person begin each episode, but that quickly changed when I could only find two women, Lisa Hartline and Deborah Ujevich, who were willing to be interviewed. If I were to move forward with this subject, I would spend more time building trust with organizations like West Virginia Family of Convicted People and other reentry programs to build more sources who would be willing to be interviewed.

Despite these limitations, I do believe that there is an abundance of stories about the criminal justice system that need to be explored. Some things my interviews revealed that could be the focus of deeper reporting include:

- The culture of "plea and release" in courtrooms. Devon Unger and other judges I interviewed for this podcast mentioned that there is a cultural norm in courtrooms to encourage people to take plea bargains so that they can be released from jail sooner. If 
someone is accused of a felony of which they are innocent, rather than wait for an unknown amount of time in jail, the person may take a plea deal offered by a prosecutor which requires the person to plead guilty to a misdemeanor, so they're able to be released that day.

- The Pretrial Risk Assessment Tool and its results. Lawyers like Jocelyn Rosnick and Alex Shalom at the ACLU both argue that the PSA used in New Jersey and Ohio is a good start for bail reform, but it's not enough because of the racial bias it produces in its results. The tool uses data from the criminal justice system around the country and because there are a disproportionate number of people of color incarcerated, the results produced in the tool tend to bring worse outcomes for those people.

- The relationship of the police and prosecutors to confidential informants and the pressure on those accused to inform on others. People who have been arrested are often forced into situations where they have to either comply with police or face charges that are as harsh as those assessed on a person accused of the crime. Both Deborah Ujevich and Lisa Hartline experienced situations in which they were either penalized or threatened with harsh sentences for failure to inform on significant others in their lives. At a panel discussion on justice reform I attended at WVU in the summer of 2019, public defenders talked about their concern for the safety of parolees, who were being asked to inform as a condition of their parole. I would like to explore how common this is and who are the individuals who tend to suffer the most from being confidential informants. 
- The power of county prosecutors. When I asked lawyers why legislation like HB 2419 fails to work, the number one answer was that we should not focus on policy to reform the system but focus on the culture of prosecutors instead. Prosecutors have the ability to relax the kinds of crimes they pursue and relax the plea deals they make with people who willingly take them in order to be released from jail more quickly.

The most important suggestion regarding reporting on the criminal justice system is to focus it on the individuals who go through the system. I believe there is great power in sharing the stories of formerly incarcerated people and those working on the ground every day inside prisons and jails. They understand better than anyone else what is currently happening and what could happen with reform. 


\section{Appendix A}

\section{Episode by Episode Production Notes}

* Music in each episode will be downloaded from Killer Tracks. The Reed College of Media at West Virginia University has a free membership available for students to use. This is subject to change due to any music copyright rules at West Virginia Public Broadcasting.

\section{An overview of the reform and reasons for the legislation.}

- Story: This episode would kick off with attorney Lisa Hartline's story (Ihartline@lawv.net). Hartline was in and out of North Central and South Central Regional Jails multiple times from 2002 to 2006 on various drug and tax charges. She served four-and-a-half months in North Central Regional Jail in $\mathbf{2 0 0 5}$ for a felony possession with intent to deliver cocaine. She couldn't afford the $\$ 50,000$ bond the court set, so she waited for her trial in jail. The court eventually released her on home confinement and then dropped the charges a year later because of a lack of evidence. Her narrative would flow throughout this first episode as she talks about her experience not being able to afford bond and what it was like to wait in the regional jails.

- Narration: I will connect her story to the number of people waiting in regional jails and will cite the report from Reuters that says that West Virginia regional jails have the highest death rate in the country.

○ 7,571 inmates died in 500 U.S. jails from 2008-2019. At least two-thirds of the inmates tracked by Reuters-4,998 people-were found not guilty of the crime they were arrested for.

- Out of 500 jails in the report, WV has the highest rate of jail deaths, and more than $50 \%$ above the national average. 111 inmates died in the 10 regional jails between 2009-2019.

- More than $1 / 3$ deaths from medical condition or illness

o More than $1 / 4$ deaths from suicide

- Voices: Betsy Jividen (304-280-7004)- Commissioner of the WV Division of Corrections and Rehabilitation. Though she is the commissioner of the WV Division of Corrections and Rehabilitation, she has a history of advocating for justice reform. She could describe the landscape of the justice system in the state and reasons why the jails are so crowded and incarceration numbers keep rising and reasons why the jails are so crowded and incarceration numbers keep rising.

- Delegate John Shott (304-340-3252) could also be a voice in this episode. A story that explains why he sponsored the legislation could be effective in this episode. 
- Narration: Quenton King's report from WV Policy

- On 10/29/20-458 pretrial misdemeanors in regional jails

o On 10/29/20-2,116 pretrial felons in regional jails

- Voices: Clips of other interviews that could highlight what is to come in next episode and rest of the podcast

- Narration: I need to tease the rest of the podcast and let the listener know what they will learn in following episodes.

\section{Where is the state in the process of implementation now.}

- Story: Someone who was released from jail because of COVID, someone who hasn't been released since the reform was passed. Places to search for people like this are through advocates like Lida Shepherd, Lisa Hartline and other people who have been through the system.

- Narration: Discuss how many people have been released because of COVID-19, how many people have been released because of HB 2419 and discuss what the legislation says judges can do and what it mandates, if anything.

- Voice: Lida Shepherd (LShepherd@afsc.org) can comment on the process of advocating for the bill, or others like these to be passed and the status of the state's willingness to release nonviolent offenders due to COVID-19. Shepherd works with American Friends Service Committee's WV Economic Justice Project, a community organizing and advocacy program. She has led advocacy efforts toward bills such as Ban the Box, Easy ID, the ban on SNAP benefits for drug felons and expungement legislation.

- Narration: I will need to introduce the theme of next episode and tease it to keep the audience engaged.

\section{Who might be adversely affected.}

- Story: This episode should look at people who have reservations about letting people out of jail on their own recognizance and possible fallouts.

- Interviewees should include a representative of the bail bonds industry, a person who opposes bail reform out of fear of continued criminal activity and state legislators such as Delegate Trenton Barnhart or Delegate Jason Barrett who voted against the bill. There were 8 Democrats and 13 Republicans who voted against the bill. One of them should be able to comment about why that is.

- Kaci Kisner, office manager at Bill's Bail Bonds in Morgantown.

- Narration: Should include data about how the bill could economically affect the bails bonds industry. Other data could include the economic prosperity of the bonds industry in the state. 
- Narration: Will need to tease the final episode here.

\section{How is bail reform going at other places in the country, and what could that mean for West Virginia?}

- Story: The stories in this episode could include someone who can speak to what could happen to West Virginia if the state does not act at all on bail reform, someone who opposed bail in another state and what happened when it was abolished or someone in the district attorney's office in another state. The story in this episode will anchor in either the personal potential benefits or potential harms from ending cash bail. Potential interview with administrative director of New Jersey courts Judge Glenn Grant who's praised the reforms to the bail system the state made three years ago.

- Voices: Lawrence A. Krasner is the district attorney of Philadelphia, and two years ago his office announced it would no longer for a list of offenses that made up $61 \%$ of all cases in the city's courts. An interview with him can describe how the legislation passed in Philadelphia has helped reduce the number of people incarcerated.

- Voice: Governor Andy Beshear of Kentucky has pushed for state lawmakers to pass criminal justice reforms, including abolishing the money bail system. His interview can explain how Kentucky, a state in Appalachia, is trying to reform the system and reduce the number of people incarcerated in the state.

- Narration: Explaining other state's reforms, i.e. California, New York and Illinois abolishing cash bail. How is it going? Other states like Kentucky are using other ways besides abolishing cash bail to reform the bail system. Oklahoma has one of the highest rates of incarceration in the world, but bail lays on the shoulders of nonprofits in the state.

- Voices: Representative of Still She Rises, Tulsa (media@stillsherises.org) is an organization that helps women living in poverty pay for money bail. Representative of The Bail Project Inc., ((323) 366-0799), nonprofit organization that helps to pay bail for those who can't afford it. Office located in Cleveland, $\mathrm{OH}$ in the case of interviewing an employee or executive.

- Narration: I will need to wrap up the podcast here by reminding the audience where West Virginia's legislation stands and who is still working for the system to change one way or another. 


\section{Appendix B}

\section{Interview Guide}

Interviewer: Hello, my name is Patrick Orsagos, and I'm a graduate student at West Virginia University. In pursuance of my Master of Science in Journalism, I am creating a podcast about bail reform in West Virginia. I've reported on the mass incarceration of women in the state for the past two years, and I've noticed that the intricacies of the subject, specifically bail reform have gone under-reported by state media. I'm hoping to address the fallout of the bail system and how a new bill aiming to reduce the number of people assigned bail could change it.

I would like to ask you questions about your understanding of bail reform's effects on West Virginians, and the economic factors and implications of the passing of House Bill 2419. Answering these questions is completely voluntary. With your consent, your identity and parts of your interview will be featured in the podcast, which may be presented to the public. I will be

recording the interview with an audio recorder. Your answers will be transcribed at a later time. At any time, you may stop the interview. The interview will likely take 60 to 90 minutes.

Do you have any questions?

Are you ready to begin?

For documentation purposes, I would like to confirm that I am interviewing on at (name, date, time).

\section{Interview Questions:}

Questions for people who have gone through the bail process:

1. Why were you arrested and were you assigned bail? If so, how much?

2. If you were not able to afford it, how long did you wait in jail?

3. Were you charged for the crime you were arrested for?

4. Can you describe what happened as a consequence of staying in jail? For example ....job loss, separation from family?

5. If you were charged with a crime, how long was your sentence? Did you spend any of that sentence in a regional jail? If so, for how long? 
6. How did your time incarcerated affect your relationship with your family? Your mental health and your physical health?

*I intend to get answers to questions 5-6, but for the purposes of broadcast storytelling, I will be asking each person interviewed to describe some of the details of these experiences.

Questions for bail bondsman:

1. How long have you worked in the bail bonds business?

2. Is it your main source of income, if not, what is?

3. Are you familiar with the bill that was passed in January that would allow judges to release certain nonviolent offenders on their own recognizance? If not, the bill is aimed to reduce the number of people incarcerated for nonviolent misdemeanors.

4. All 10 regional jails have been overcrowded within the last 10 years. Betsy Jividen, commissioner of WV Corrections has been quoted saying the regional jails are "bursting at the seams." Has the overcrowding of the jails impacted your business? If so, how?

Questions for the state delegates who sponsored the bill:

1. What prompted your sponsorship of the bail reform bill?

2. What did you hope this would look like when implemented specifically?

3. What kinds of challenges did you find getting this bill passed into law? I noticed on the history of the bill's status on the legislature's website that it was amended a couple times. I noticed there was a request for a name change, but other than that, were there any amendments to the bill that drastically changed it?

4. Other states like New York and California are reforming bail, even abolishing the cash bail system. Could this legislation develop toward more reforms revolving bail?

5. I know that this legislation was passed in March 2020, but what is the current implementation of it? Has it been altered or changed since the COVID-19 pandemic shut down the state in mid-March?

Questions for judges:

1. How have your views on the bail system changed or not changed throughout your career as a judge?

2. Do you believe the bail system in the state is working and why do you believe it is/isn't working?

3. What is your process for deciding the amount of bail? Is it solely based on whatever crime the person is accused of committing, or are there other factors?

4. Do you see a future with the cash bail system and why or why not?

5. How do you respond to critics of the system who say that bail is assessed unevenly? 
6. What do you believe is leading to the overcrowding of the prisons and jails in West Virginia?

7. In your opinion, how can the overcrowding be reduced?

Questions for interviewees from other states reforming bail:

1. Your state has high rates of incarcerated people, similar to West Virginia, how are the jails? Are they overcrowded? If so, how much?

2. How has bail been reformed or how is it being reformed in your state? Who has been affected the most by those reforms?

3. What role does your organization play in helping those who cannot afford bail to pay for it?

4. What do you hope to see your state do to reform bail?

5. If your state has abolished cash bail, how will that affect the bail bondsman in your state?

6. On average, do you know how many people who've been found not guilty had to sit in jail, as a result of not paying bail?

Thank you for your thoughtful answers. I appreciate the time you have given me today. Do you have anything else you would like to add before we end the interview? If you think of something you'd like to share, please feel free to contact me.

Again, I want to thank you for your time and I wish you the best.

Demographics:

Name:

Gender:

Age:

Level of education:

Current job: 


\section{Appendix C \\ Interview questions for podcast subjects post production (For Reflection on Research Questions)}

1. What are your initial thoughts about the reporting on bail reform in West Virginia after listening to the podcast?

2. How well did I explain the landscape of bail reform and the arguments for and against it in West Virginia?

3. What is your perception of my bias and viewpoints regarding the bail system?

4. What makes you answer question three in the way you did?

5. How well did I do at helping people understand your experiences/perspective?

6. Are there other perspectives that should have been explored?

7. What aspects of bail reform do you think should still be covered or talked about in future reporting? 


\section{Appendix D \\ Official Interview Notes}

1. Lisa Hartline, Attorney at Southwest Pennsylvania Legal Aid

a. I interviewed Lisa Hartline at her house in Washington, Pennsylvania in January 2021. She was my first interview for the podcast and one of the central characters in my reporting. She grew up in West Virginia and spent many years in and out of the criminal justice system in the state. In our interview, we spoke about her upbringing, her experiences being incarcerated as a result of not being able to afford bail, her reentry into society and her experience becoming a lawyer after being released.

2. Quenton King, Policy Analyst at the West Virginia Center on Budget and Policy

a. Quenton was my second interview. The interview was conducted at his house in Charlestown, West Virginia. We spoke about a report he published about the number of counties in the state struggling to pay regional jail bills. He explained some of the reasons why a number of counties can't afford the jail bills and how HB 2419 was not helping to reduce the number of people incarcerated in regional jails. He was a key interview in explaining how a lack of data in the criminal justice system makes it more difficult for targeted legislation to make meaningful reforms.

3. Sara Whitaker, Kanawha County Public Defender:

a. Sara Whitaker is a public defender in Kanawha County. We spoke on background about the court process such as the initial court hearings, when lawyers first speak to clients and how long someone typically waits to know whether or not they're assigned bail. She also spoke candidly about the downfalls of HB 2419. She said that it was not written in a way that required a mandatory change in the way judges or magistrates distribute bail.

4. Brian S West, Deputy Public Advocate for the Kentucky Department of Public Advocacy in Frankfort, Kentucky:

a. At the end of January, I connected with Brian S West over the phone. He is the Deputy Public Advocate for the Kentucky Department of Public Advocacy. He and I spoke about the administrative release program in the state. This program allows for certain nonviolent offenders to be released from jail without ever stepping in front of a judge. The program was expanded in March 2020 due to the COVID-19 pandemic. As the year progressed, the number of releases did begin to decrease, which was counter to the goal of the program. We also spoke about the pretrial risk assessment tool used in the state and other ways his office has advocated for reforming the bail system. 
5. Delegate Danielle Walker, 15th District in the WV House of Delegates, Democrat:

a. Delegate Danielle Walker and I met over Zoom to speak on background about HB 2419 , bail reform in the state and ways to connect with delegates who were more heavily involved in the legislation. She connected me with Delegate Barbara Fleischauer, who has co-sponsored similar bills in the past, and Delegate Brandon Steele, who voted against HB 2419.

6. Delegate Barbara Fleischauer, 51st District in the West Virginia House of Delegates, Democrat:

a. I visited Delegate Fleischauer at her home in Morgantown. We spoke about the differences between HB 2419, the bail reform bill passed in 2020, and HB 2190, a similar bail reform bill that did not pass in 2019. The main difference between these two bills was the required time limit for an incarcerated person to first stand before a judge. In HB 2419, the time limit was 3 days and in HB 2190, the time limit was 10 days. I did not use this interview in the podcast because it ended up not being relevant to any of the episodes.

7. Delegate Brandon Steele, 29th District in the West Virginia House of Delegates, Republican:

a. Delegate Brandon Steele and I met over Zoom during the legislative session in Charleston. In our conversation, Delegate Steele told me about why he voted against HB 2419. His thoughts were that the bill did not actually do enough to change the way bail is distributed in the state. He also said that in Raleigh County, the district he represents, the judges, magistrates and lawyers have a working relationship where incarceration isn't always the first answer for a nonviolent, nonsexual misdemeanor offense.

8. Delegate John Shott, 27th District in the West Virginia House of Delegates, Republican:

a. Delegate Shott and I were scheduled to meet at his office in Bluefield, but extreme winter weather shifted the interview to a phone call. As the lead sponsor of HB 2419, he and I spoke about why he believed the legislation was necessary, his opinions on how the bill changed through the amending process and his views on the outcomes of the law. In our discussion, Shott told me that it was not very clear whether or not the bill applied to both nonviolent felonies and misdemeanors. He also told me that the 3 day hearing limit was very difficult for smaller counties to achieve because of small staff sizes and large numbers of incarcerated people.

9. Chuck Miller, Kanawha County Prosecuting Attorney:

a. Chuck Miller and I spoke over the phone about his interpretation of HB 2419 and how he advises his employees to interpret the law. He said that he does not see the law applying to felonies because the purpose of the bill is to release low 
level, nonviolent offenders. I reached out to Miller after hearing anecdotally from lawyers at the Kanawha County Public Defender's Office that the county prosecutors were not enforcing the law.

10. Staci Kisner, Owner of Bill's Bail Bonds, Morgantown:

a. Staci and I met in her office in Morgantown. We spoke about the history of her bail bonds business and her thoughts on bail reform. Our interview was excellent because Kisner is a great example of how a bondsman can operate to help release people from jails. Kisner said bondsmen are an important industry because they help to release people from jail without costing the taxpayer any money. If reforms to the bail system put too much power on the state to track incarcerated people, then taxpayers will be the ones paying for it.

11. Devon Unger, Staff Attorney at West Virginia Innocence Project and Melissa Giggenbach, Program Director at West Virginia Innocence Project:

a. I met with Devon Unger and Melissa Giggenbach, two lawyers working at the West Virginia Innocence Project. We spoke about the project and their thoughts on the effectiveness of HB 2419. After an initial interview, I arranged a second interview exclusively with Devon Unger. Unger is a former public defender and private defense attorney. He believes HB 2419 does qualify for both nonviolent felonies and misdemeanors. He also explained to me why he believes the bill does not do enough to mandate a change in the way a judge or magistrate assigns bail.

12. David Bourne, spokesperson for Professional Bail Agents of the United States and a Bail Agent in Virginia:

a. David Bourne and I spoke over the phone in early April. He is a spokesperson for the Professional Bail Agents of the United States (PBUS). He spoke to me about his work and why he believes the bail bonds industry is important to maintain. Like Kisner, Bourne says it's important for the bail bonds industry to stay afloat so that taxpayers are not the ones paying for the state to find people who missed court dates or to help release people from jail. He also mentioned that bail bonds are essential to public safety because if a judge or magistrate releases a dangerous person without bail, then there will be no bondsmen to help decrease the probability of that person hurting themselves or someone else.

13. Jocelyn Rosnick, Policy Director at the American Civil Liberties Union of Ohio

a. Jocelyn Rosnick is a policy director at the ACLU of Ohio. She has worked on advocating for reforms to the bail system in her state. We spoke about Ohio's bail system, how the system has been reformed in recent years and what other reforms Rosnick and the ACLU would like to see happen. She also spoke about the pretrial risk assessment tool used in some counties in the state and the 
ACLU's stance on the tool. Rosnick also referred me to Anthony Body, a bail disruptor at The Bail Project.

14. Anthony Body, Bail Disruptor at The Bail Project

a. Anthony Body and I spoke over Zoom about his work as a bail disruptor at The Bail Project in Cleveland, Ohio. In his role, Body receives a list of people currently in jail, who could be eligible for release, from the public defender's office in Cuyahoga County. He then spends most of his day in the jails in the county interviewing people who could be eligible for services like mental health, housing support, substance abuse rehabilitation and even pretrial release services. Body is not a lawyer, but he works alongside them to help clients any way he can.

15. Ashley Spalding, Research Director at Kentucky Center for Economic Policy:

a. Ashley and I spoke over the phone about her research of the bail system in Kentucky. Earlier in 2020, she published a report titled "Disparate Justice: Where Kentuckians Live Determines Whether They Stay in Jail Because They Can't Afford Cash Bail" which showed how differently bail was assigned in each county in the state. In addition to her report findings, she spoke with me about the administrative release program in Kentucky, as well as the pretrial risk assessment tool used in the state.

16. Deborah Ujevich, Detox Intake Coordinator in Cross Lanes and Community Organizer for WV Families of Incarcerated People:

a. Deborah and I spoke over the phone. Our interview was scheduled to be inperson, but extreme winter weather shifted the conversation to a phone call. We spoke about her experiences incarcerated and her inability to pay bail. Deborah's ex-finance was caught searching through an apartment unit on his job site. It was later discovered that he was selling drugs. In the investigation, the police visited Ujevich to question her. She ended up arrested for obstructing an office, charged with conspiracy and was incarcerated for $\mathbf{2 0}$ months because she could not afford the $\$ 20,000$ bond set for her. She served her time, and now she works at a detox center in Cross Lanes and as a community organizer for the WV Families of Incarcerated People.

17. Alexander Shalom, Senior Supervising Attorney and Director of Supreme Court Advocacy at the American Civil Liberties Union of New Jersey:

a. Alex and I met over Zoom to discuss the complete reformation of the bail system in New Jersey. He walked me through the legislation that passed in 2017 that implemented the assumption that all people charged with a crime, other than those facing life imprisonment, are deemed innocent and should not be held in jail pretrial. When someone is arrested, a police officer has two choices; they can give someone a summons, which happens for most low level offenses, or they 
can issue a warrant. A summons is just a ticket that tells the person to show up in court on a certain date. A warrant is what you would typically imagine as a usual arrest. The police officer handcuffs the person and takes them to the police station. New Jersey uses a Public Safety Assessment, but Shalom said the PSA doesn't make a definitive decision. A lawyer is present with a defendant at every stage, even the initial hearing, which happens 24-48 hours after an arrest.

18. Joseph Pate, Press Manager, The Bail Project

a. Joseph and I spoke over the phone and over email about the specific duties of a bail disruptor. It was important for me to adequately explain some of the job duties of a bail disruptor because it is somewhat of an uncommon job. He also connected me with Franklin Cruz.

19. Franklin Cruz, Senior Policy Advisor, The Bail Project

a. Franklin Cruz and I spoke over Zoom about general bail reform in various states across the country. I scheduled this interview with him to specifically address reforms in New York and California. After the interview, I realized that his remarks were great information about the two states, but it was not important enough for me to include it in the podcast. He was based in Washington D.C., so I did not see him as the best expert interview for those two states. However, I did learn a lot about reforms more generally to bail systems around the country. 


\section{Appendix E}

\section{Episode Production Notes}

The outlining, scripting, editing and revising of each episode was done in an on-going process as interviews were completed and transcribed. Because the potential themes for each episode outlined in the methodology were merely a starting off point, I allowed the stories brought forth from interviews to decide how each episode would be shaped. The section below will summarize the subject and themes selected for each.

\section{Episode One- The Human Cost of Bail}

To introduce the podcast, I decided to fully ground the audience with Lisa Hartline's narrative. I knew that the subject matter, HB 2419 and bail reform, was a complicated and oftentimes confusing subject for someone outside of criminal justice work. For this reason, I wanted to humanize the subject matter. The first episode weaves between Lisa's upbringing and her experiences while incarcerated with the current state of the bail system in the state. I used facts and statistics that I could back up with Lisa's experiences while incarcerated. I also had to explain how bail works, and to avoid a lengthy segment of only my voice, I used her experience to explain how the system functions. At the end of the episode, I segued into the second episode by introducing Quenton King, the policy analyst at the West Virginia Center on Budget and Policy and HB 2419 which is the law that is analyzed and dissected throughout the remainder of the podcast.

Episode Two- West Virginia's Bail Reform Bill: How it Works and Who it Serves

In episode two, I tasked myself with explaining the need for a bail reform bill like HB 2419 and how that bill actually played out. I also wanted a character in this episode to humanize the data and legal jargon-like talk that would come from explaining legislation. Quenton King fit the role of the main character for the episode. His interview was the most attention-grabbing and being in-person, I could use the sound from our interactions to layer the story. After he shared his findings, I shifted the focus to the three of the main issues with HB 2419: there are a number of crimes listed on the bill that if committed, are excluded from qualifying for personal recognizance; lawyers can't agree on whether the law applies to both nonviolent felonies and misdemeanors; and the law doesn't say what judges or magistrates should do in any clear way. I also wanted to show that this was not a Republican versus Democrat issue. Delegates in both parties seem to agree that there are too many people in regional jails, but they seem to disagree about how to fix that. To close episode two, I briefly compared how other states have modified or reformed their respective bail systems and highlighted some of the positive changes HB 2419 created, like a time limit for an initial hearing. 
Episode 3- A Family Business is Focused on Releasing People from Jail, Keeping the Community $\underline{\text { Safe }}$

Episode three was challenging to piece together because many bail bondsmen in the area did not want to be interviewed when I told them the subject of the podcast was exploring bail reform efforts. I spoke with Kaci Kisner on multiple phone calls before she agreed to sit down and speak with me. I really enjoyed our conversation, and I think she is one of the most thought-provoking interviews in the podcast. I humanized bondsmen through telling her story to show that she is someone who cares deeply about helping people get out of jail.

I struggled to find a second voice in this episode that could provide more context to the need for the bonds industry, but David Bourne remedied the situation. His voice is used to explain some of the legal jargon used in the bail industry and to present an additional argument of the need for the bonds industry, which is that it helps to ensure victim and offender safety. A common argument from those who oppose bail reform is that it endangers public safety. I wanted to be sure I presented that argument in an adequate way for the audience to decide what they thought of it.

Episode 4- A Tour of Bail: How Other States have Reformed the Money Bail System

To conclude the podcast, I covered how other states were reforming their bail systems to compare how West Virginia stacks up. This was the most difficult episode to produce because of the vastness of potential angles. I hoped to speak with officials in Illinois, California and New Jersey because those three states had the most drastic reforms or the most news around reforms. After many failed attempts to connect with officials in California and Illinois, I decided to pursue other avenues. I found a series of stories about bail reform efforts from the Department of Public Advocacy in Kentucky. I realized Kentucky could be an important state for comparison as its demographics are similar to West Virginia's. West connected me with Ashley Spalding at the Kentucky Center for Economic Policy. The state's administrative release program offered a different kind of reform that didn't abolish the bail system, but offered an alternative way to alleviate the number of cases a judge or magistrate needs to see. Through additional research, I read that Ohio had been making small changes to the bail system throughout the past decade. I first reached out to the ACLU because I believed they would connect me with other key players in the conversation. My interview with Jocelyn Rosnick was excellent to learn about the background of recent reforms and she connected me with Anthony Body at The Bail Project. His job as a bail disruptor became the hook for the episode. I thought that his story was the most interesting and compelling, and he was one of the only interviews I conducted of someone working on the ground in jails. Ultimately, I did connect with the ACLU of New Jersey after multiple attempts. I originally hoped to connect with Chief Justice Stuart Rabner, who took lead in a large part of the reforms. Alex Shalom was a great interview because he was a member on the committee to create the reform plan. I started the episode 
with Kentucky because its reforms are the newest and the administrative release program increased at the start of the COVID-19 pandemic. I transitioned to Ohio because both Kentucky and Ohio use the same pretrial risk assessment tool. Finally, I ended with New Jersey because the reforms were the oldest and most drastic. 


\section{References}

Abdelfatah, R., Arablouei, R. (Executive Producers). (2020, September 3). Reframing History: Mass Incarceration. Throughline. NPR. https://www.npr.org/transcripts/899441920

Allen, E. (2020, January 29). W.Va. House Passes Bail Reform Bill Aimed at Reducing Jail Overcrowding. West Virginia Public Broadcasting. https://www.wvpublic.org/news/2020-01-29/w-va-house-passes-bail-reform-bill-aimedat-reducing-jail-overcrowding

American Bail Coalition. (2020, March 5). West Virginia Bail Reform Moves Forward While Other States Go the Other Direction. American Bail Coalition: Ensuring Accountability In the Criminal Justice System.

https://ambailcoalition.org/west-virginia-bail-reform-moves-forward-while-other-

$\underline{\text { states- }}$

go-the-other-direction/

Barrau-Adams, F. (Executive Producer). (2018, July 25). Justice in America Episode I: Justice for the Rich, Money Bail (No. 1). The Appeal. https://theappeal.org/justice-in-america-episode-1-justice-for-the-rich-money-bail/

Benjamin, D. (2017, June 2). Episodic vs. Thematic Stories. FrameWorks.

https://www.frameworksinstitute.org/article/episodic-vs-thematic-stories/

Born, M. (2018, June 13). In West Virginia, SNAP Benefits Out for Reach for Drug Felons. West Virginia Public Broadcasting.

https://www.wvpublic.org/news/2018-06-13/in-west-virginia-snap-benefits-out-of- 


\section{-for-drug-felons}

Boorstin, D.J. (2012). From Hero to Celebrity: The Human Pseudo-Event. The Image. A Guide to Pseudo-Events in America. (45-77). New York: Vintage Books.

Bureau of Justice Statistics. (2020 March). Jail inmates in 2018. U.S. Department of Justice Office of Justice Programs Bureau of Justice Statistics. https://www.bjs.gov/content/pub/pdf/ji18.pdf

Chico, M., \& Moore, K. (2020). KIDS Program Allows Infants to Stay with Incarcerated Mothers up to 18 Months at Lakin. Women Beyond Bars. https://www.womenbeyondbars.com/kids-program-allows-infants-to-stay-with-

$\underline{\text { incarcer }}$ ated-mothers-up-to-18-months-at-lakin/

Coleman, R., \& Thorson, E. (2002). The Effects of News Stories that Put Crime and Violence Into Context: Testing the Public Health Model of Reporting. Journal of Health Communication, 7(5), 401-425.

College of Journalism and Communications University of Florida. (2019, April 10). Major New Podcast Study Reveals Listener Habits, Trust in Host. College of Journalism and Communications University of Florida.

https://www.jou.ufl.edu/2019/04/10/major-new-podcast-study-reveals-listener-habits- 
Corrections Statistical Analysis Tool. (2019). Office of Justice Programs at the Bureau of Justice Statistics. Retrieved May 6, 2020, from https://www.bjs.gov/index.cfm?ty=nps

Cosimini, M., Cho, D., Liley, F., Espinoza, J. (2017, June). Podcasting in Medical Education: How Long Should a Podcast Be?. Journal of Graduate Medical Education. 9(3), 388-389. Doi:

\subsection{0/JGME-D-17-00015.1}

DeCarli, M. (2020). Restorative Justice Gains Ground for Young People in West Virginia. Women

Beyond Bars.

https://www.womenbeyondbars.com/restorative-justice-gains-ground-for-young-

people

-in-west-virginia/

De La Cruz. P, McNemar, R. (2020). Decrease in Incarcerated Population in Response to Covid-19

Increases Need for Re-Entry Resources in WV. Women Beyond Bars.

https://www.womenbeyondbars.com/decrease-in-incarcerated-population-in-

response-

to-covid-19-increases-need-for-re-entry-resources-in-wv/

Delmar, A. (2016, May 9). What Is the Optimal Length for a Podcast?. We Edit Podcasts. 
https://www.weeditpodcasts.com/what-is-the-optimal-length-for-a-podcast/

DiFilippo, D. (2017, October 23). Philly activists raising money to bail poor defendants out of jail.

WHYY PBS/NPR.

https://whyy.org/articles/philly-activists-raising-money-bail-poor-defendants-jail/

Dowling, D. O., \& Miller, K. J. (2019). Immersive Audio Storytelling: Podcasting and Serial

Documentary in the Digital Publishing Industry. Journal of Radio \& Audio Media, 26(1),

167-184. https://doi-org.wvu.idm.oclc.org/10.1080/19376529.2018.1509218

Entman, R. M. (1993). Framing: Toward clarification of a fractured paradigm. Journal of

Communication, 43(4), 51-58.

Gandy, O. (1994). From Bad to Worse-The Media' Framing of Race and Risk. Media Studies

Journal. 8(3), 39-51.

Gamson, W. A., \& Modigliani, A. (1989). Media discourse and public opinion on nuclear power: A constructionist approach. American Journal of Sociology, 95, 1-37.

Gross, K. (2006). Emotional Response to News Framing of Crime. Conference Papers International Communication Association, 1-27.

Harold, Z. (2013, June 24). Claims of sexual misconduct at prisons, jails costing state millions. Charleston Gazette-Mail. 
https://www.wvgazettemail.com/news/politics/claims-of-sexual-misconduct-at-prisons-

i

ails-costing-state-millions/article 106b0084-8b34-58f5-a6d1-a436e70a4874.html

Herbert, D. (Executive Producer). (2020, March 3). Podcast: The Debate Over Money Bail

Reform. Arnold Ventures.

https://www.arnoldventures.org/podcasts/podcast-your-money-or-your-freedom/

Herring, T. (2020, November 17). Bail Reform: Reducing Pretrial Populations and Protecting

Public Safety. The Crime Report.

https://thecrimereport.org/2020/11/17/bail-reform-reducing-pretrial-populations-andpublic-safety/

lyengar, S. (1990). Framing responsibility for political issues: The case of poverty. Political Behavior, 12, 19-40.

Iyengar, S. (1991). Is anyone responsible? How television frames political issues. Chicago, IL: University of Chicago Press.

Iyengar, S. (2010). Framing research: The next steps. In B. Schaffner \& P. Sellers (Eds.), Winning with words: The origins and impact of political framing (pp. 185-191). New York, NY: Routledge

Jenkins, J. (2018, October 31). Questions remain in connection with Whitey Bulger murder. The Dominion Post. https://www.dominionpost.com/2018/10/31/questions-remain-in-connection-with-

$\underline{\text { whit }}$

ey-bulger-murder/ 
Justice Community Services. (2019 August). 2015 West Virginia Recidivism Report. WV Recidivism Rates. https://dcr.wv.gov/resources/Documents/publications/Recidivism\%202015.pdf

Kidd, W. (2012). Utilising podcasts for learning and teaching: a review and ways forward for e-Learning cultures. Management in Education (Sage Publications, Ltd.), 26(2), 52-57. https://doi-org.www.libproxy.wvu.edu/10.1177/0892020612438031

Lantigua-Williams, J. (Executive Producer). (2019, July 29). How Bail Shackles Women of Color (No. 3). 70 Million Podcast. Lantigua-Williams \& Co. https://70-million.simplecast.com/episodes/how-bail-shackles-women-of-color-x9fYsCG $\underline{Y / \text { transcript }}$

Lantigua-Williams, J. (Executive Producer). (2018, October 21). How New Orleans Could Set a New Course for Bail Reform (No. 9). 70 Million Podcast. Lantigua Williams \& Co. https://70-million.simplecast.com/episodes/how-new-orleans-could-set-a-new-course-f or-bail-reform-gJD7o29X/transcript

LegiScan. (2020). Roll Call: WV HB2419 / 2020 / Regular Session. LegiScan Bringing People to the Process. https://legiscan.com/WV/rollcall/HB2419/id/945912

Lindgren, M. (2016). Personal narrative journalism and podcasting. Radio Journal, 14(1), $23-41$. https://doi.org/10.1386/rjao.14.1.23 1

Matthes, J. (2009). Framing Responsibility for Political Issues: The Preference for Dispositional Attributions and the Effects of News Frames. Communication Research Reports, 26(1), 82-86. https://doi-org.wvu.idm.oclc.org/10.1080/08824090802637114

Melamed, S. (2017, November 8). Can a Philly community bail fund fix our criminal-justice 
system?. Philadelphia Inquirer.

https://www.inquirer.com/philly/news/crime/can-a-philly-community-bail-fund-fix-our-

$\underline{c}$

$\underline{\text { riminal-justice-system-20171108.html\#loaded }}$

Melamed, S. (2019, February 19). Philly DA Larry Krasner stopped seeking bail for low-level

crimes. Here's what happened next. Philadelphia Inquirer.

https://www.inquirer.com/news/philly-district-attorney-larry-krasner-money-bail-

$\underline{\text { crimin }}$

al-justice-reform-incarceration-20190219.html? vfz=medium\%3Dsharebar

Mistich, D. (2018, October 30). Whitey Bulger, Boston Gangster, Killed in 'Apparent Homicide' at West Virginia Prison. West Virginia Public Broadcasting.

https://www.wvpublic.org/news/2018-10-30/whitey-bulger-boston-gangster-killed-in-

$\underline{a p}$

parent-homicide-at-west-virginia-prison

Osbourne, H. (2020, May 29). San Marcos cite-and-release, first law in Texas, in effect Sunday. Statesman.

https://www.statesman.com/news/20200529/san-marcos-cite-and-release-law-first-in-

$\underline{\mathrm{t}}$

exas-in-effect-sunday

Orsagos, P. (2020, May). More than a quarter of women serving prison sentences in WV are in jails. Women Beyond Bars. 
https://www.womenbeyondbars.com/more-than-a-quarter-of-women-serving-prison-

$\underline{\text { se }}$

ntences-in-wv-are-in-jails/

Pan, Z., \& Kosicki, G. (2001). Framing as a strategic action in public deliberation. Framing

Public Life, 51-82

Pierson, L. (2020, March 7). Legislators passed bail and parole reforms this session, but work on the state's jail system remains. Charleston Gazette-Mail.

https://www.wvgazettemail.com/news/legislative session/legislators-passed-bail-and-p arole-reforms-this-session-but-work-on-the-states-jail-system/article 4b6d0e15-e3d2-5 $\underline{3 c 3-872 \mathrm{c}-435 \mathrm{ea} 75 \mathrm{e} 3183 . \mathrm{html}}$

Pierson, L. (2020, March 4). Senate committee hesitantly approves bail and parole reforms with three days left in session. CHarleston Gazette-Mail.

https://www.wvgazettemail.com/news/legal affairs/senate-committee-hesitantly-

appro

ves-bail-and-parole-reforms-with-three-days-left-in-session/article 9b1b0f94-1988-

$\underline{5079}$

$\underline{-942 b-02161 \mathrm{e} 41 \mathrm{fd} 62 . \mathrm{html}}$

Pierson, L. (2019, November 11). A prison guard stalked and abused imates in Alderson. Now they're suing him and the U.S. government. Charleston Gazette-Mail. https://www.wvgazettemail.com/news/legal affairs/a-prison-guard-stalked-and-

abused- 
inmates-in-alderson-now-theyre-suing-him-and-the/article f49e832e-ed22-5b53-85ab-

\section{9fa04b9fa53.html}

Plum, K. (2018, November 16). Hazelton prison workers picket to raise awareness of understaffing. The Dominion Post. https://www.dominionpost.com/2018/11/16/hazelton-prison-workers-picket-to-raise-a wareness-of-under-staffing/

Prison Policy Initiative (2019). United States Profile. Prison Policy Initiative. https://www.prisonpolicy.org/profiles/US.html\#time

Prison Policy Initiative (2019, October). Women's Mass Incarceration: The Whole Pie 2019. Prison Policy Initiative. https://www.prisonpolicy.org/reports/pie2019women.html

Saab, A. (2018). WV Drug Court Provides Second Chances, Reduces Recidivism. Women Beyond Bars. https://www.womenbeyondbars.com/wv-drug-court-provides-second-chances-reducesrecidivism/

Sawyer, W. (2017, June 22). New government report points to continuing mental health crisis in prisons and jails. Prison Policy Initiative. https://www.prisonpolicy.org/blog/2017/06/22/mental_health/ Scardina, C. (2018). Aural Language: Podcasting as a Tool of Expression. Teacher Librarian, 46(1),

34-36.

Schreiner, B. (2020, January 21). Kentucky high court asked to fix 'badly broken' bail system. 
Associated Press. https://apnews.com/article/9722edf8c4387bdc9b595558b2af7457

Smith, G. (2020, October 16). Jail deaths in America: data and key findings of Dying Inside.

Reuters Investigates.

https://www.reuters.com/investigates/special-report/usa-jails-graphic/

So, L. (2020, December 17). West Virginia lawmakers push jail reform in response to Reuters data

on inmate deaths. Reuters.

https://uk.reuters.com/article/us-usa-jails-westvirginia/west-virginia-lawmakers-push-

jai

I-reform-in-response-to-reuters-data-on-inmate-deaths-idUSKBN28R36Z

Solutions Journalism Network (2020). SolutionsU. Solutions Journalism Network.

https://solutionsu.solutionsjournalism.org/

Solutions Journalism Network (2020). Who We Are. Solutions Journalism Network.

https://www.solutionsjournalism.org/who-we-are/mission

Staff. (2018, October 30). Notorious mobster James "Whitey" Bulger found dead in federal prison

in WV. NBC12 WBOY.

https://www.wboy.com/news/crime/notorious-mobster-james-whitey-bulger-found-

$\underline{\text { dea }}$

d-in-federal-prison-in-wv/1562120619/

Tanner, C. (2020). New Bail Reform Could Decrease Jail Population in WV. Women Beyond Bars. 
https://www.womenbeyondbars.com/new-bail-reform-could-decrease-jail-population-

in

$\underline{-w V /}$

Thompson, M. (2018, August). Case Study: The Reentry Project. The Whole Story Ideas

and Dispatches from the Solutions Journalism Network.

https://thewholestory.solutionsjournalism.org/case-study-the-reentry-project-4a6fdde6

$100 d$

United States Sentencing Commission (2017, October). Mandatory Minimum Penalties for Drug Offenses in the Federal System. United States Sentencing Commission.

Vera Institute (2017, November). A Path to Recovery: Treating Opioid Use in West Virginia's Criminal Justice System. Vera Institute of Justice.

https://www.vera.org/publications/a-path-to-recovery-treating-opioid-use-west-

virginia-

criminal-justice-system

https://www.ussc.gov/research/research-reports/mandatory-minimum-penalties-drug-

$\underline{0}$

Ffenses-federal-system

Vera Institute (2019, December). Incarceration Trends in West Virginia. Vera Institute of Justice. https://www.vera.org/downloads/pdfdownloads/state-incarceration-trends-west-

$\underline{\text { virgini }}$

a.pdf

West Virginia Press Association (2020). WV Newspapers. WV Press Association. 
https://wvpress.org/wvnewspapers/

West Virginia Division of Corrections and Rehabilitation. (2003). PREA (Prison Rape Elimination Act). West Virginia Division of Corrections and Rehabilitation. https://dcr.wv.gov/resources/Pages/prea.aspx

West Virginia Legislature. (2020, March 7). Committee Substitute for HB 2419. West Virginia Legislature 2nd Session of the 84th Legislature. https://www.wvlegislature.gov/Bill Status/bills text.cfm?billdoc=HB2419\%20SUB\%20E NR.htm\&yr=2020\&sesstype $=$ RS\&i $=2419$

White, J. (2019). Substance Abuse Treatment In Demand at Lakin Correctional Center. Women Beyond Bars. https://www.womenbeyondbars.com/substance-abuse-rehabilitation-in-wv-prisons/

(2020) Resolve Philadelphia. The Center for High Impact Philanthropy School of Social Policy and Practice University of Pennsylvania. https://www.impact.upenn.edu/resolve-philadelphia/

(2018, November 27) 2 officers injured after being assaulted by inmate in West Virginia. CBS13 WOWK. https://www.wowktv.com/news/west-virginia/2-officers-injured-after-being-assaulted-

$\underline{\mathrm{b}}$

y-inmate-in-west-virginia/

(2019, December 1). NJ now a leader in showing that bail reform works as expected. The Press of Atlantic City. https://pressofatlanticcity.com/opinion/editorials/nj-now-a-leader-in-showing-that-bail- 
reform-works/article e0797479-e90b-5f2c-bfff-a045ce145bff.html 